\title{
Article \\ Poly(imidazolium) Carbosilane Dendrimers: Synthesis, Catalytic Activity in Redox Esterification of $\alpha, \beta$-Unsaturated Aldehydes and Recycling via Organic Solvent Nanofiltration
}

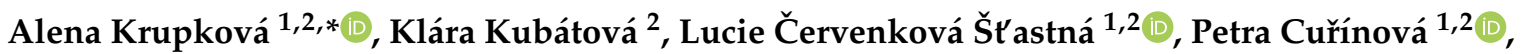 \\ Monika Müllerová ${ }^{1,2}$, Jindřich Karban ${ }^{1}{ }^{\mathbb{D}}$, Jan Čermák ${ }^{1,2}$ and Tomáš Strašák ${ }^{1,2, *}$ \\ 1 Institute of Chemical Process Fundamentals of the CAS, v.v.i., Rozvojová 135, 16502 Prague, Czech Republic; \\ stastna@icpf.cas.cz (L.Č.Š.); curinova@icpf.cas.cz (P.C.); mullerovam@icpf.cas.cz (M.M.); \\ karban@icpf.cas.cz (J.K.); Cermak@icpf.cas.cz (J.Č.) \\ 2 Faculty of Science, J.E. Purkyně University in Ústí nad Labem, Pasteurova 15, \\ 40096 Ústí nad Labem, Czech Republic; klarkakubatka006@seznam.cz \\ * Correspondence: krupkova@icpf.cas.cz (A.K.); strasak@icpf.cas.cz (T.S.)
}

check for updates

Citation: Krupková, A.; Kubátová,

K.; Červenková Št'astná, L.; Cuřínová,

P.; Müllerová, M.; Karban, J.; Čermák,

J.; Strašák, T. Poly(imidazolium)

Carbosilane Dendrimers: Synthesis,

Catalytic Activity in Redox

Esterification of $\alpha, \beta$-Unsaturated

Aldehydes and Recycling via Organic Solvent Nanofiltration. Catalysts 2021, 11, 1317. https://doi.org/10.3390/ catal11111317

Academic Editors: Agnieszka Siewniak and Victorio Cadierno

Received: 30 September 2021

Accepted: 28 October 2021

Published: 29 October 2021

Publisher's Note: MDPI stays neutral with regard to jurisdictional claims in published maps and institutional affiliations.

Copyright: (C) 2021 by the authors. Licensee MDPI, Basel, Switzerland. This article is an open access article distributed under the terms and conditions of the Creative Commons Attribution (CC BY) license (https:/ / creativecommons.org/licenses/by/ $4.0 /)$.

\begin{abstract}
Three series of poly(ionic) carbosilane dendrimers peripherally functionalized with imidazolium groups substituted on N-3 with methyl, isopropyl and 2,6-diisopropylphenyl (Dipp) were prepared up to the 3rd generation together with model monovalent imidazolium iodides and used as $\mathrm{N}$-heterocyclic carbene (NHC) precursors. Catalytic activity of model and dendritic NHCs generated in situ by deprotonation with DBU was tested in redox esterification of $\alpha, \beta$-unsaturated aldehydes and the influence of substitution, dendrimer generation, temperature and substrate structure on the reaction outcome was evaluated. Dipp substituted NHCs showed high activity and selectivity in the reaction with primary alcohols. Effectiveness of organic solvent nanofiltration for the recycling of dendritic NHCs was demonstrated on the 1st generation Dipp substituted catalyst in model redox esterification of cinnamaldehyde with benzyl alcohol. A marked increase in both activity and selectivity in the first four reaction runs was observed and this improved performance was preserved in the following catalytic cycles.
\end{abstract}

Keywords: immobilization; organocatalysis; N-heterocyclic carbenes; umpolung; poly(cationic) dendrimers; nanofiltration

\section{Introduction}

Azolium salts can act as effective organocatalysts [1,2], providing catalytically active species with different mechanisms of substrate activation [3-5]. Besides simple activation of substrates' nucleophilic center by hydrogen bonding or ion-pair interaction, enabling e.g., cycloaddition of carbon dioxide to epoxides [6,7], they can serve as precursors of N-heterocyclic carbenes (NHCs). These subtle species generated by deprotonation of azolium salts offer an entirely unique active site through the carbene atom and its tunable surroundings, able to promote a broad range of chemical transformations [8-11]. Over the last two decades, the practical application of so called umpolung principle provided access to a wide library of compounds $[12,13]$. Nevertheless, while many aspects of NHCcatalyzed umpolung reactions, such as activity and selectivity of the catalysts, were studied and optimized, only few studies dealing with the problem of catalyst separation and reuse have been reported so far, moreover, they were limited to benzoin condensation [14-16] and Stetter reaction [17].

Increasing the sustainability of homogeneous catalytic processes and overcoming the major drawback of organocatalysis, i.e., high catalyst loading, by means of catalyst recycling is still a challenge. Recently we developed a branched fluorous tag designed for easy fluorophilization of various substrates [18,19]. Highly fluorophilic imidazolium salts bearing this tag were used as NHC precursors and applied in redox esterification carried 
out in fluorous biphase system, which allowed for their effective recycling [20]. Such solution allows the reaction to proceed in fully homogeneous mode, but it is unsuitable for continuous processes. Accordingly, immobilization or incorporation of a homogeneous catalyst in a solid (inorganic or polymeric) support still remains a predominant approach for the separation of catalysts from reaction mixtures [21], although the homogeneity of the active site is lost to some extent. Many types of immobilized ionic liquids (ILs) on different supports, such as silica [22], MOFs [23], zeolites, various nanoparticles and other materials, have been described [24]. Somewhat surprisingly, soluble macromolecules, such as dendrimers, are much less utilized, in spite of their potential advantages.

Dendrimers, as highly branched macromolecules with regular, tunable structure and low polydispersity due to a well-controlled synthesis [25], can be considered as chemical individuals, despite of their size. They seem to be ideally suited for the attachment of functional moieties at defined positions, yielding their multivalent analogs as optimal systems to study multivalency and the effect of immobilization. Several methods have been proposed for the recovery of dendrimers from reaction mixtures [26,27], nevertheless most of them makes use of different solubility of components and phase separation [26,28-30]. There are also some reports on magnetically recoverable dendrimers and catalysts with dendritic ligands utilizing their interaction with magnetic nanoparticles [31,32]. Recovery methods based on molecular enlargement of the active group, employing membrane processes for the separation of the homogeneous catalyst and other reaction components, are reported much less than it would correspond to the high suitability of this approach for dendritic catalysts. Dialysis in commercially available membrane bags, a slow, diffusiondriven process, is mostly used [33,34]. Despite low efficiency of early attemps [35], a substantial effort was made to develop the method [36,37].

We have previously tested carbosilane dendritic supports for immobilization of both metal-based [38] and metal-free catalysts, which recycling by means of organic solvent nanofiltration (OSN) [39] was also accomplished [40]. OSN proved to be a very effective method, enabling separation of homogeneous reaction components under mild conditions with low energy and material input. This study expands our previous research to another type of catalysts and aims to the preparation of multivalent NHCs. We describe the influence of the attachment of imidazolium salts to dendritic supports on their catalytic performance in redox esterification, their activity towards a wide variety of substrates and their recycling by OSN. We also report the positive effect of OSN on the activity of multivalent NHC catalyst, leading to increase of reaction rate in subsequent reactions.

\section{Results and Discussion}

\subsection{Synthesis and Characterization}

For this study, three novel series of monovalent models and multivalent dendritic catalysts were prepared using the synthetic protocol that we have recently developed for the preparation of related cationic carbosilane compounds; a thorough description of synthesis and characterization data can be found in the Experimental Section and in the published papers [40,41]. The final synthetic step involving quaternization of imidazoles with either model 3-iodopropylbutyldimethylsilane or 3-iodopropyl-terminated dendrimers is depicted in Scheme 1. 


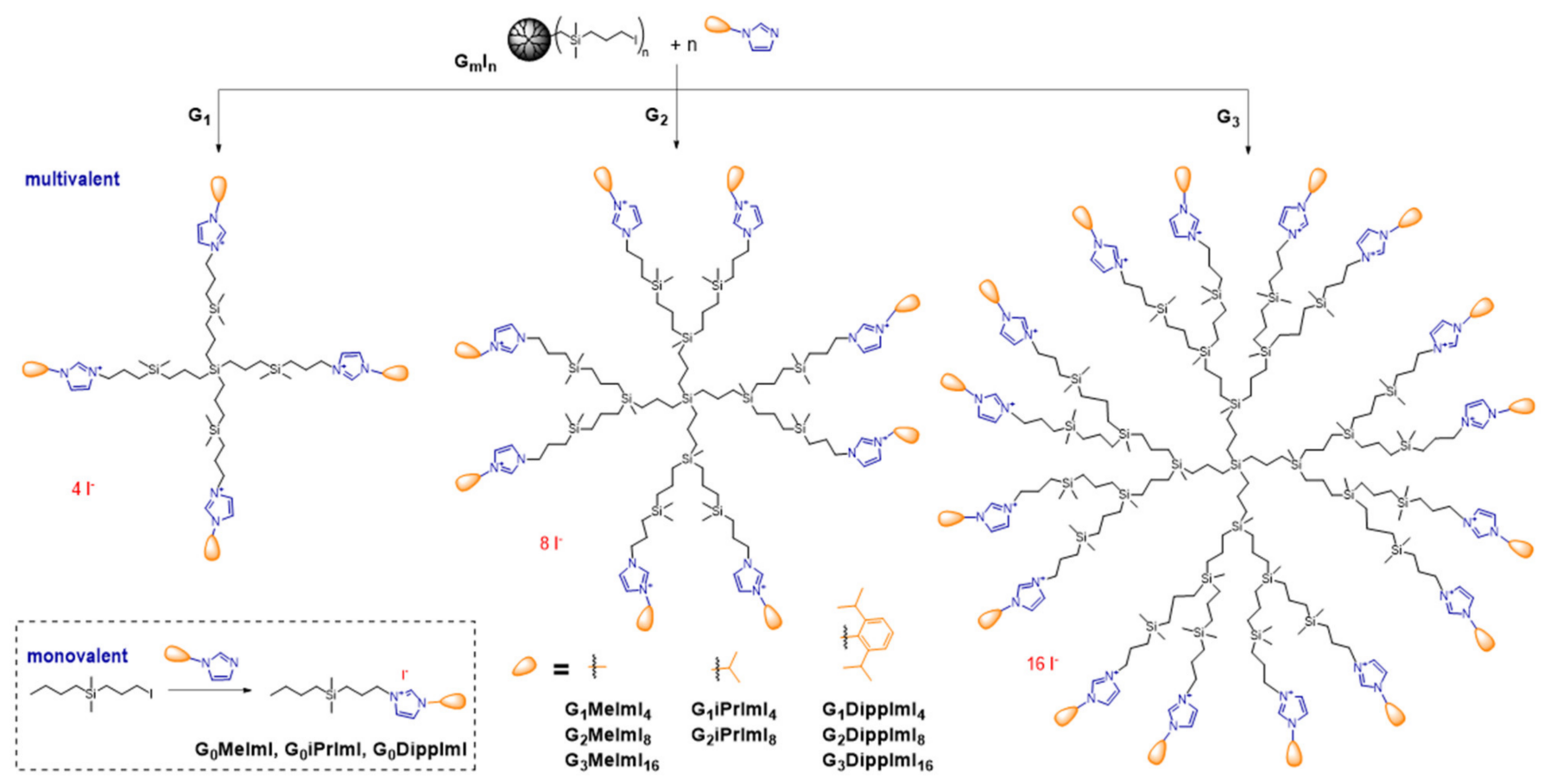

Scheme 1. Synthesis of model and dendritic imidazolium precatalysts.

Whereas the quaternization step with methyl- and isopropylimidazole is nearly quantitative according to both NMR and ESI MS spectra (Supplementary Material), giving almost monodisperse products, the reaction with hindered diisopropylphenylimidazole (DippIm) is less effective, which leads to defects in the structure at higher generations and lower loading of imidazolium units. HRMS showed the presence of iodopropyl and/or hydroxypropyl-terminated branches, the same types of defects we have reported previously for poly(phosphonium) carbosilane dendrimers [42]. The sum of quaternization-related defects typically did not exceed $5 \%$ as estimated from ${ }^{1} \mathrm{H}$ NMR and HRMS (with the excep-

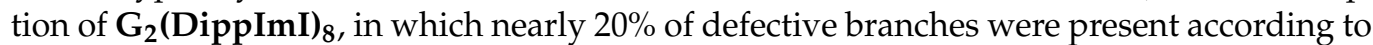
${ }^{1} \mathrm{H}$ NMR). However, as the quantification is rather inaccurate due to peak overlap and the progress of catalysis is quite insensitive to such small differences in catalyst concentration, the calculation of catalyst loading was based on the nominal number of active groups in the molecule without defects.

\subsection{Screening of Catalysts}

All model imidazolium salts were tested as precatalysts of redox esterification of cinnamaldehyde and benzyl alcohol (Table 1). This reaction is often used as a benchmark allowing facile evaluation of the catalytic performance of newly prepared compounds $[43,44]$. Preliminary experiments were performed at $100{ }^{\circ} \mathrm{C}$ in toluene, with $10 \mathrm{~mol} \%$ catalyst loading and $10 \mathrm{~mol} \%$ of the base (DBU); dioctyl phthalate was added as an inert standard to enable accurate quantification of GC-FID data. As evident from entries 1 and 5, the catalysts generated from methyl- and iso-propyl-substituted model imidazolium salts $\mathbf{G}_{0} \mathbf{M e I m I}$ and $\mathbf{G}_{0} \mathbf{i P r I m I}$ by deprotonation showed similar performance to previously described fluorinated analogs, for which also a superior activity of the methyl-substituted compound was observed [20]. To our delight, the third model $\mathbf{G}_{0}$ DippImI bearing a sterically demanding 2,6-diisopropylphenyl (Dipp) group manifested by far the highest activity, reaching the full conversion of the starting aldehyde in less than 20 min (entry 8) and confirming the previously observed positive influence of bulky aryl substituents on azolium on the catalyst performance [45]. All three models showed high selectivity for the formation of saturated ester and only small quantities of byproducts 4 and 5 a reported previously to accompany this reaction [20] were detected by GC (Table 1). 
Table 1. Screening of catalysts and reaction conditions in redox esterification of cinnamaldehyde with benzyl alcohol.

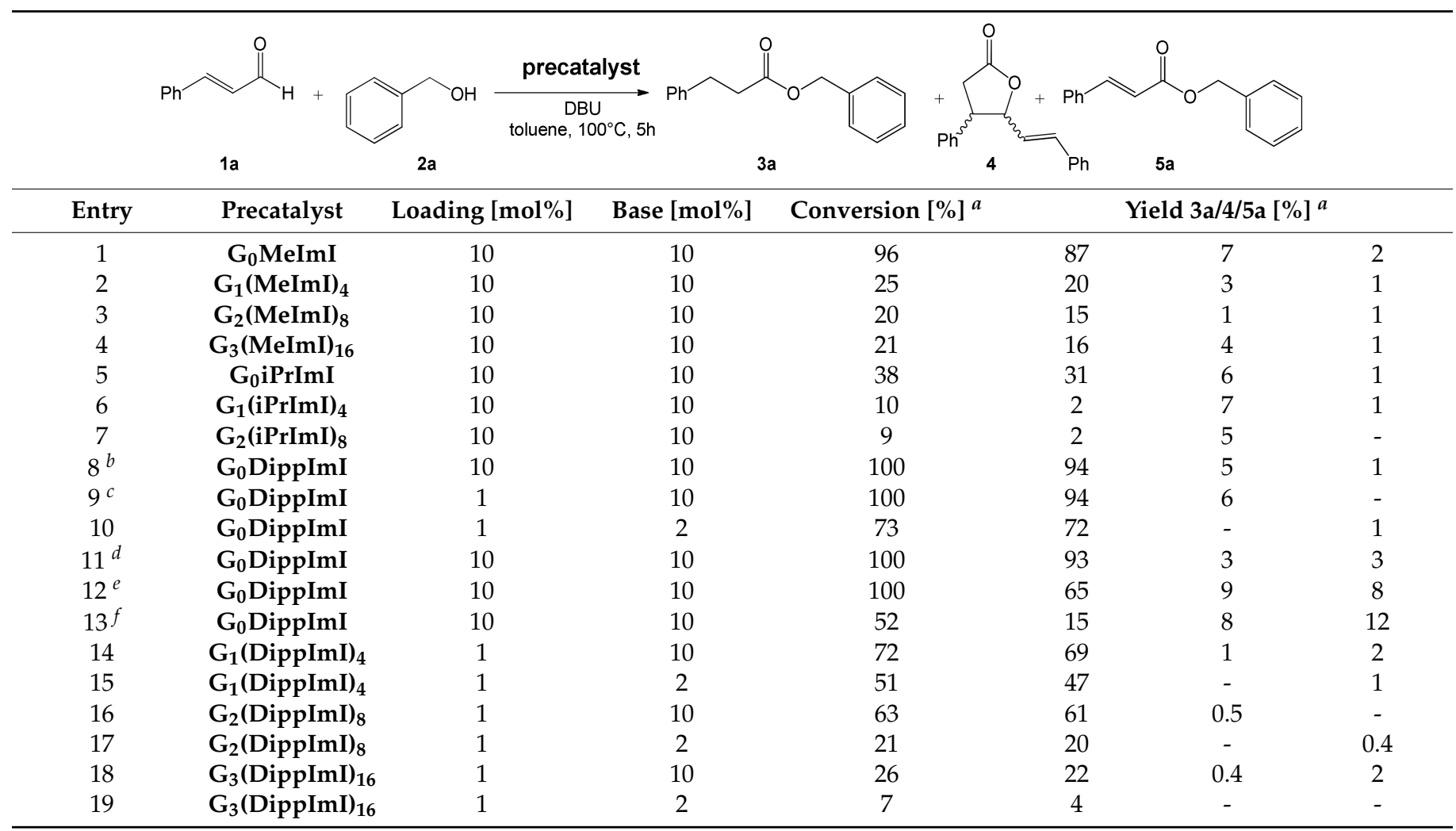

${ }^{a}$ As determined by GC according to internal standard; ${ }^{b}$ reaction time $20 \mathrm{~min} ;{ }^{c}$ reaction time $90 \mathrm{~min} ;{ }^{d}$ reaction temperature $80^{\circ} \mathrm{C}$, reaction time $3 \mathrm{~h} ;{ }^{e}$ reaction temperature $60^{\circ} \mathrm{C} ;{ }^{f}$ reaction temperature $40{ }^{\circ} \mathrm{C}$.

Exploiting the unprecedented high activity of $\mathrm{G}_{0}$ DippImI, we examined the influence of the reaction temperature (Figure 1a) and decrease in catalyst loading. It turned out that lowering the reaction temperature has a detrimental effect on selectivity and overall yield, benzyl cinnamate $\mathbf{5 a}$ being the major side product at low temperature (entry 13). A similar change in selectivity was previously observed by Scheidt et al. for triazolium and imidazolium-based NHC catalysts in enantioselective redox esterification carried out at low temperature $[46,47]$. On the other hand, lowering the amount of the precatalyst to $1 \mathrm{~mol} \%$ (with twofold excess of the base) had a positive effect on selectivity while the reaction rate was still fair (entry 10). The reaction rate could also be boosted by the use of larger excess of the base (10-fold to the catalyst) which, however, slightly lowered the selectivity (entry 9). It is clear that the base plays multiple role in the reaction and it serves not only to generate the active NHC moiety, but also facilitates other transformations in the catalytic cycle, as already suggested by Sohn and Bode [48].

Next, we examined the effect of the dendritic scaffold in the benchmark reaction. As apparent from Figure 1, a negative effect of immobilization was observed in all cases. Methylimidazolium derived dendritic catalysts showed a severe drop in activity compared to the model compound even in the first generation, while the differences between generations 1, 2 and 3 were negligible (Figure 1b). This behavior can be ascribed to a close proximity of active sites leading to preferential formation of intramolecular adducts between NHC and imidazolium moieties stabilizing the carbene and lowering its activity as an organocatalyst [11]. The dendrimers bearing isopropylimidazolium groups not only had a very low activity, but at the same time they exhibited poor selectivity (entries 6, 7), so they were excluded from further studies. On the other hand, in case of DippIm series the deactivation is not so severe and it is clearly generation dependent (Figure 1c). Again, the addition of excess base had a positive influence on the reaction rate ( $c f$. Figure 1c,d), albeit less pronounced than in case of the corresponding model. Considering the amount of 
defects in $\mathbf{G}_{\mathbf{2}}$ (DippImI $)_{8}$, the activity of one particular active site is very similar for $\mathrm{G}_{1}$ and $\mathrm{G}_{2}$ catalyst when large excess of base is used. Under the same conditions the activity of $\mathrm{G}_{3}$ catalyst remained somewhat lower, although experiencing the largest increase (three times higher reaction rate). It seems clear that the bulky Dipp substituent effectively hinders the formation of adducts and it is responsible for the higher activity of this type of dendritic catalysts. The observed negative dendritic effect can be rationalized by a restricted mobility of active sites residing at the periphery of a dendrimer and their uneven distribution in solution (variable local concentration of catalyst), which implies lower probability of effective collisions with the base and substrates.
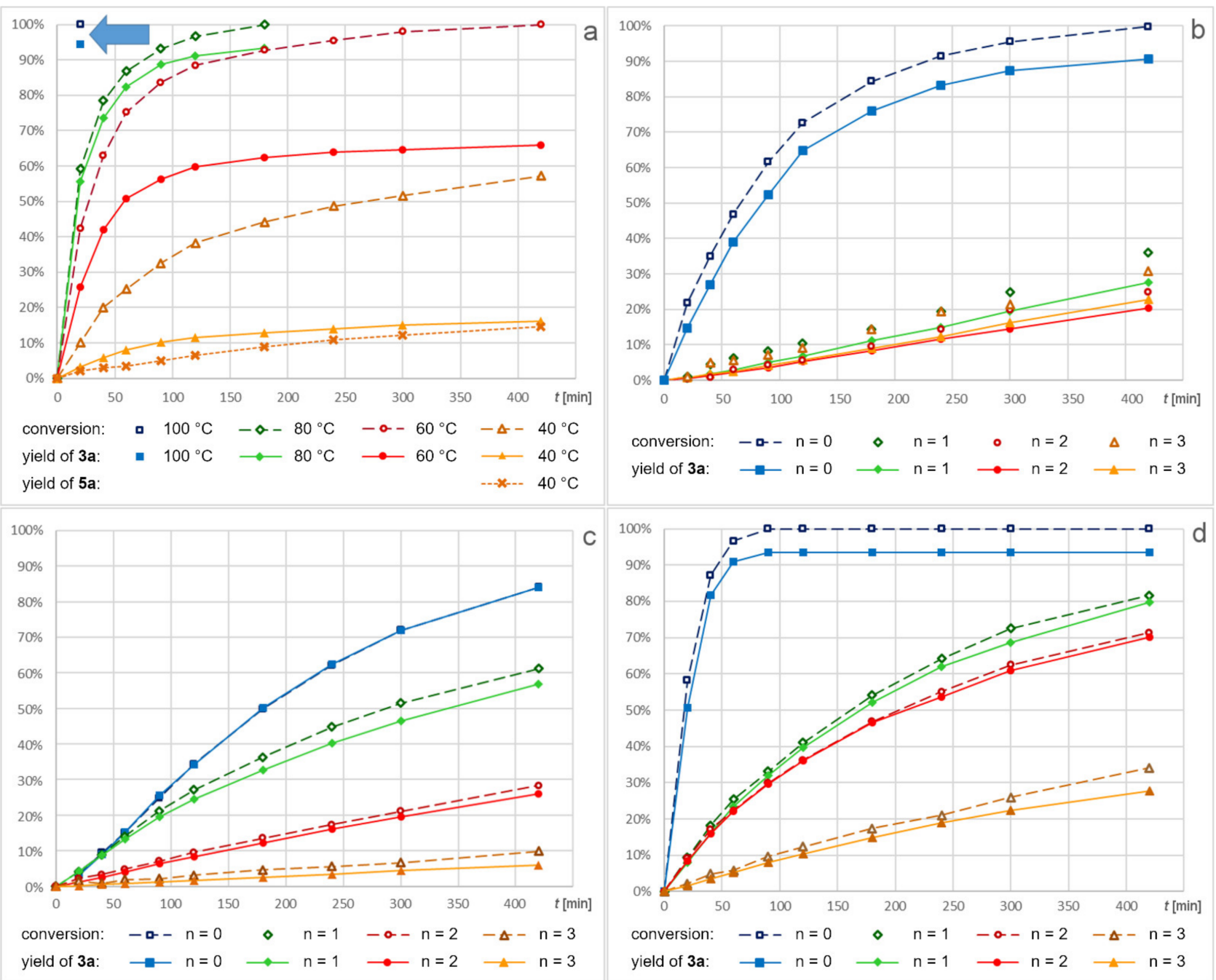

Figure 1. Time course of redox esterification of cinnamaldehyde with benzyl alcohol (4 equiv) in toluene; (a) effect of temperature on the reaction catalyzed by $\mathrm{G}_{0} \operatorname{DippImI}(10 \mathrm{~mol} \%$; DBU $10 \mathrm{~mol} \%)$; (b) $100{ }^{\circ} \mathrm{C}$, influence of the support, precatalyst from methylimidazolium series $\mathbf{G}_{\mathbf{n}}(\mathbf{M e I m I})_{\mathbf{m}}(\mathrm{n}=0-3,10 / \mathrm{m} \mathrm{mol} \%$; DBU $10 \mathrm{~mol} \%)$; (c,d) $100{ }^{\circ} \mathrm{C}$, influence of the support and amount of the base, precatalyst from Dipp imidazolium series $\mathbf{G}_{\mathbf{n}}(\mathbf{D i p p I m I})_{\mathbf{m}}(\mathrm{n}=0-3,1 / \mathrm{m} \mathrm{mol} \%$; DBU $2 \mathrm{~mol} \%$ (c), $10 \mathrm{~mol} \%$ (d)). 


\subsection{Screening of Substrates}

Whereas the influence of the aldehyde structure on the course of redox esterification was extensively studied $[43,48]$ and novel precatalysts were designed and synthesized to overcome the low reactivity of $\alpha$-substituted enals [49], much less is known about the role of the other reaction component-the alcohol. Most studies use only simple primary alcohols $(\mathrm{MeOH}, \mathrm{EtOH}, \mathrm{BnOH})$ and underestimate the possible influence of the alcohol structure, especially when sterically demanding mesityl and Dipp substituted NHCs are used. To evaluate the influence of the substrate structure on the reaction progress, the model $G_{0}$ DippImI and dendritic precatalysts $\mathbf{G}_{\mathbf{1}}(\operatorname{DippImI})_{4}$ and $\mathbf{G}_{\mathbf{2}}(\operatorname{DippImI})_{\mathbf{8}}$ were tested in the redox esterification of 1a with selected alcoholic substrates representing various structural types (products depicted in Figure 2, data sorted according to alcohol type in Table 2). To allow a straightforward comparison between individual substrates and catalysts, the loading was set to $2 \mathrm{~mol} \%$ of active sites (imidazolium groups) and $4 \mathrm{~mol} \%$ of DBU in all cases, in spite of supposed lower activity of dendritic catalysts. In cases where the selectivity was fair but a large decrease in the reaction rate was observed when going from the model to dendritic catalysts, also the experiments with higher catalyst loading (10 mol\% of active sites and 10\% of DBU) were carried out. The reaction progress was monitored by CG-FID with sampling after 5, 24 and $100 \mathrm{~h}$.<smiles>O=C(CCc1ccccc1)OCc1ccccc1</smiles>

3a $98 \%(96 \%)$<smiles>O=C(CCc1ccccc1)OC1CCCC1</smiles>

3e $82 \%\left(81 \%^{b, *}\right)$<smiles>CCCCOC(=O)CCc1ccccc1</smiles>
3b $91 \%\left(75 \%{ }^{*}\right)$<smiles>O=C(CCc1ccccc1)OC1CCCCC1</smiles>
3f $74 \%\left(78 \%{ }^{\mathrm{b}, *}\right)$<smiles>C=CCOC(=O)CCc1ccccc1</smiles>
3c $96 \%(83 \%)$<smiles>O=C(CCc1ccccc1)OC1CCCCCC1</smiles>
3 g $66 \%^{c}\left(64 \%{ }^{b, *}\right)$<smiles>C#CCOC(=O)CCc1ccccc1</smiles><smiles>CC1(C)C2CCC1(C)C(OC(=O)CCc1ccccc1)C2</smiles>

3h $71 \%^{\mathrm{c}}\left(63 \%^{\mathrm{b}, *}\right)$<smiles>O=C(CCc1ccccc1)OCC(F)(F)C(F)F</smiles><smiles>O=C(CCc1ccccc1)OCC(Cl)Cl</smiles><smiles>CC(C)COC(=O)CCc1ccccc1</smiles><smiles>CCC(C)OC(=O)CCc1ccccc1</smiles><smiles>CC(C)=CC(=O)OCc1ccccc1</smiles>

5m $10 \%$ *<smiles>CCCCCC(=O)OCc1ccccc1</smiles>

3n $83 \%$ (39\%)<smiles>CCCC=CCCC(=O)OCc1ccccc1</smiles>

30 $66 \%\left(52 \%{ }^{a}\right)$<smiles>O=C(/C=C/C=C/c1ccccc1)OCc1ccccc1</smiles>

5o $10 \%(19 \%)$<smiles>Cc1ccc(N(C)C)cc1</smiles><smiles>CN(C)c1ccc(/C=C/C(=O)OCc2ccccc2)cc1</smiles><smiles>O=C(CCc1ccccc1[N+](=O)[O-])OCc1ccccc1</smiles><smiles>O=C(/C=C/c1ccccc1[N+](=O)[O-])OCc1ccccc1</smiles>

* incomplete conversion; ${ }^{a} \mathrm{G}_{2}$ Dipplm 8 as precatalyst; ${ }^{b} \mathrm{G}_{2}$ Melm 8 as precatalyst; ${ }^{c} \mathrm{G}_{0}$ Melm as precatalyst

Figure 2. Structures of products obtained from the substrate screening and the highest GC yields achieved with model and dendritic (in parentheses) catalysts $\left(\mathrm{G}_{0}\right.$ DippImI and $\mathrm{G}_{\mathbf{1}}(\text { DippImI })_{4}$, respectively, unless otherwise noted). 
Table 2. Yields and conversions ${ }^{a}$ obtained in redox esterification of cinnamaldehyde with various alcohols catalyzed by imidazolium dendrimers of generations 0 to $2^{b}$.

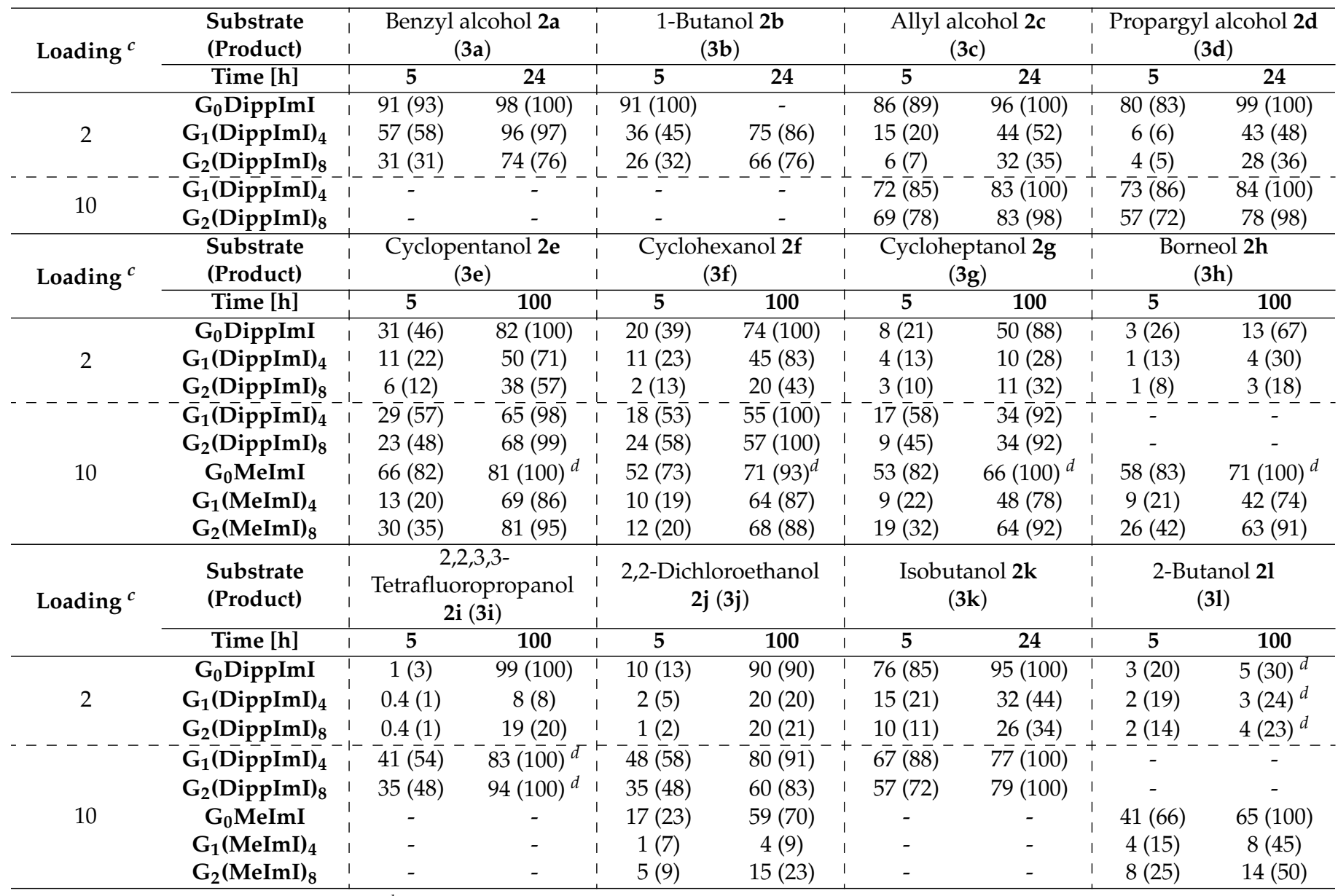

${ }^{a}$ Conversions given in parentheses; ${ }^{b}$ conditions: 4 equiv of alcohol, $100{ }^{\circ} \mathrm{C}$; yield of saturated ester and conversion of $1 \mathrm{a}$ determined by GC according to internal standard; ${ }^{c}$ loading in mol\% referring to active groups, 4 and $10 \mathrm{~mol} \%$ of DBU for 2 and $10 \mathrm{~mol} \%$ of precatalyst, respectively; ${ }^{d}$ after $24 \mathrm{~h}$.

In our recent study utilizing fluorous imidazolium as a precatalyst we have observed that the use of secondary alcohols led to a slight decrease in the reaction rate, yield and selectivity [20]. Compared to those fluorinated NHCs, Dipp substituted organocatalysts demonstrated much higher sensitivity to the structure of alcohol, even if the trends were similar. Apart from benzyl alcohol, the best results were obtained for primary alcohols without substitution at $\alpha$-carbon (2b, 2c, 2d). The reaction with $\alpha$-substituted haloalcohols $2 \mathbf{i}$ and $\mathbf{2} \mathbf{j}$ was much slower, but the selectivity remained high. Generally, the difference between the activity of the model and dendritic catalysts was larger than observed for the benchmark reaction with benzyl alcohol. Secondary alcohols were poor substrates except for unsubstituted alicyclic alcohols (2e, 2f, 2g), which gave moderate yields. Tert-butyl alcohol and phenol gave only traces of products. The lack of $G_{0}$ DippImI activity towards phenol contradicts our previous findings, as we have previously obtained fair yields of phenyl ester under the catalysis by fluorinated methylimidazolylidene [20]. A deeper insight into the complex reaction mechanism is needed to understand this unexpected behavior; a mechanistic study addressing the issue is currently underway. The typical side products (lactone 4 and unsaturated esters) were present in trace amounts (0-2\%). However, especially for the combination of less reactive alcohols and dendritic catalysts, a marked difference was observed between the consumption of the aldehyde and the overall yield, pointing to the possible formation of higher molecular weight impurities.

As the bulky Dipp substituent obviously hinders the reaction with sterically more demanding alcohols, we also tested the methylimidazolium-derived catalysts in the reac- 
tion with such substrates. Although the activity of $\mathbf{G}_{\mathbf{n}}(\mathbf{M e I m I})_{m}$ in the benchmark reaction was an order of magnitude lower than that of $\mathbf{G}_{\mathbf{n}}(\mathrm{DippImI})_{\mathrm{m}}$, the reaction rate in the case of more hindered alcohols was comparable or even higher and the selectivity was much better (Table 2). Esters of alicyclic alcohols were formed in good yields, the performance of the 2nd generation catalyst was slightly better than that of the 1st one.

Subsequently we carried out a short screening of representative $\alpha, \beta$-unsaturated aldehydes with model $\mathbf{G}_{0}$ DippImI as a precatalyst (Table 3, products depicted in Figure 2). As expected, $\alpha$-substituted aldehydes $\mathbf{1 b}$ and $\mathbf{1 f}$ did not react at all and only a trace of saturated ester was obtained with $\beta$-substituted substrate 1c; the major product in this case was the unsaturated ester $5 \mathrm{~m}$. Other tested aldehydes gave moderate to fair yields of the target products but the rate was low compared to the reaction with cinnamaldehyde. The reactions with $\mathbf{1 d}$ and $\mathbf{1 g}$ were selective and only traces of low $\mathrm{M}_{W}$ byproducts were detected by GC. In the case of 2,4-decadienal, the participation of the double bond in a larger conjugated system accelerates the reaction rate, but it also promotes the formation of the unsaturated product 5o. The lowest yield and selectivity were observed for $o$ nitrocinnamaldehyde $\mathbf{1 h}$, possibly due to the thermal instability of the enal and/or target product (a thermally induced degradation of products was observed during their isolation). Aside from aldehyde oligomers, a substantial quantity of the unsaturated ester $\mathbf{5 q}$ was also formed. When employing the dendritic catalysts $\mathbf{G}_{1}$ DippImI $\mathbf{I}_{4}$ and $\mathbf{G}_{2}$ DippImI ${ }_{8}$, again the decrease in both the rate and selectivity was observed, especially for the less activated substrate 1d (Supplementary Information, Table S1).

Table 3. Redox esterification of selected aldehydes with benzyl alcohol catalyzed by $\mathrm{G}_{0} \operatorname{DippImI}^{a}$.

\begin{tabular}{ccccc}
\hline \multirow{2}{*}{ Entry } & Substrate & $\begin{array}{c}\text { Conversion } \\
\boldsymbol{b}\end{array}$ & Product & Yield ${ }^{\boldsymbol{b}}$ \\
\hline 1 & 2-methyl-2-butenal 1b & 7 & - & - \\
2 & 3-methyl-2-butenal 1c & 12 & $\mathbf{5 m}$ & 3 \\
3 & trans-2-hexenal 1d & 96 & $\mathbf{3 n}$ & 76 \\
4 & trans,trans-2,4-decadienal 1e & 100 & $\mathbf{3 o}+\mathbf{5 o}$ & $66+10$ \\
5 & $\alpha$-methylcinnamaldehyde 1f & 2 & - & - \\
6 & 3-(4-(dimethylamino)phenyl)- & 82 & $\mathbf{3 p}+\mathbf{5 p}$ & $73+1$ \\
7 & 3-(2-nitrophenyl)-2-propenal 1h & 93 & $\mathbf{3 q}+\mathbf{5 q}$ & $45+16$ \\
\hline
\end{tabular}

${ }^{a}$ Conditions: precatalyst loading $10 \mathrm{~mol} \%, 10 \mathrm{~mol} \%$ DBU, 4 equiv of benzyl alcohol, $100{ }^{\circ} \mathrm{C}, 5 \mathrm{~h} ;{ }^{b}$ determined by GC according to internal standard.

\subsection{Recycling of Dendritic Catalysts}

To verify the feasibility of separation and repeated reuse of the prepared dendritic catalysts, a suitable protocol for catalyst recycling by organic solvent nanofiltration (OSN) was developed. The benchmark reaction was carried out as usual, only with higher loading of the catalyst ( $2.5 \mathrm{~mol} \%$ corresponding to $10 \mathrm{~mol} \%$ of active groups) which enabled to shorten the reaction time and marginalized the influence of catalyst losses due to material transfers between the reaction vessel and nanofiltration cell. We also tried to lower the excess of benzyl alcohol to 2 equiv with respect to the aldehyde. However, this led to insufficient solubility of the catalyst in the reaction mixture and another 2 equiv had to be added to reach the homogeneity. In the next cycles, the additional 2 equiv of benzyl alcohol were substituted by the same amount of tert-butyl alcohol as a cheaper and easierto-remove solvent. A separate experiment with fresh catalyst showed that this change of reaction conditions had a negligible effect on the reaction progress (Figure 3).

As summarized in Table 4, the catalyst recycling by means of OSN had a positive influence on the reaction outcome. From the first to the fourth cycle, both the activity and product purity increased, reaching a very satisfactory level (TOF $=10 \mathrm{~h}^{-1}$, purity over $97 \%$ ). The isolated catalyst was analyzed by HRMS after each cycle (Supplementary Information, Figure S1). The results suggest that a certain part of active groups stays in the form of NHC which is stable enough [49] to outlast the nanofiltration, and this fraction increases with 
increasing number of reaction/nanofiltration cycles due to repeated washing of iodide salt of DBU ([DBUH]I) off from the dendrimer. This can explain the observed increase in activity (better solubility and shifted equilibrium $\mathrm{Im}^{+}+\mathrm{DBU} \leftrightarrows \mathrm{NHC}+\mathrm{DBUH}^{+}$) as well as the markedly lower dendrimer recovery in the first nanofiltration cycle (the most extensive loss of $\mathrm{HI}$ from dendrimer). The higher reactivity of recycled catalyst was confirmed by a direct comparison of reaction kinetics with a fresh catalyst; more importantly, we have demonstrated that the recycled catalyst exhibited significant catalytic activity even in the absence of base (Figure 3) while fresh $\mathbf{G}_{\mathbf{1}}(\mathrm{DippImI})_{\mathbf{4}}$ showed no activity under such conditions. Considering that these tests were performed one month after the last cycle and meantime the recycled catalyst was stored on air in ambient temperature, the carbene moiety exhibits remarkable stability.

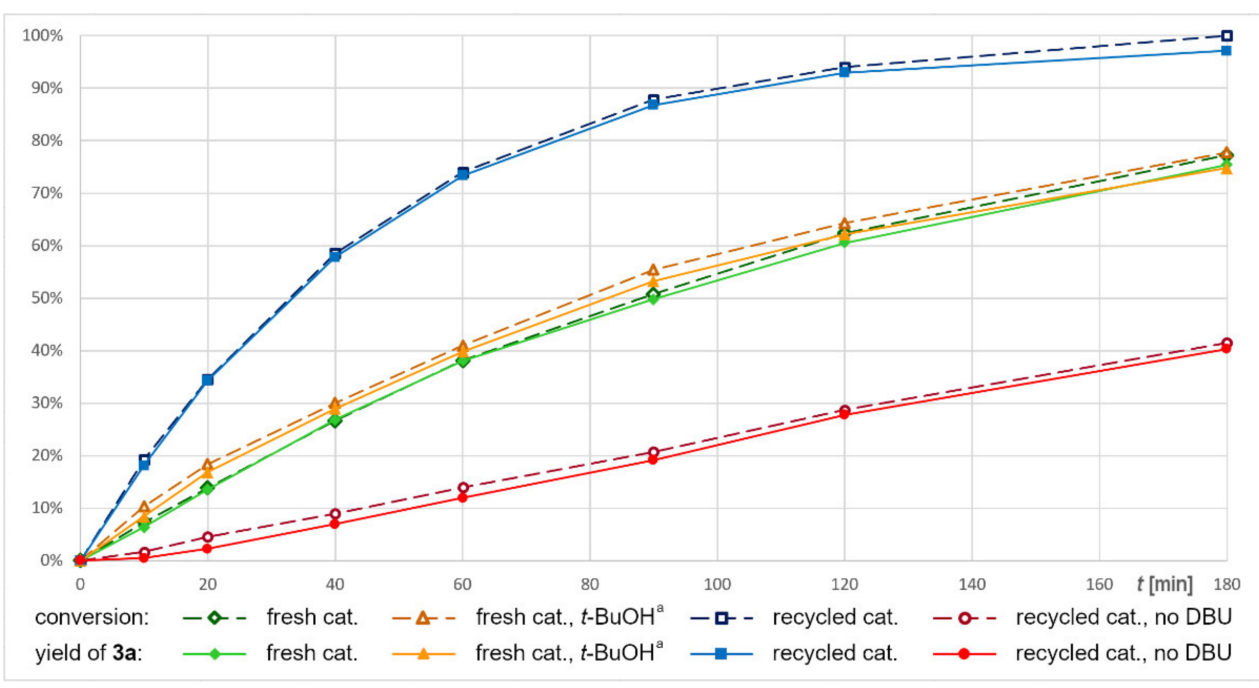

Figure 3. Comparison of the activity of fresh and 6 times recycled $\mathrm{G}_{\mathbf{1}}(\mathrm{DippImI})_{\mathbf{4}}(2.5 \mathrm{~mol} \%)$ in the redox esterification of cinnamaldehyde (4 equiv of benzyl alcohol, toluene, $100{ }^{\circ} \mathrm{C} ; 10 \%$ DBU unless otherwise noted). ${ }^{a} 2$ equiv of benzyl alcohol were replaced by tert-butyl alcohol.

Table 4. Recycling of $\mathrm{G}_{1}(\text { DippImI })_{4}$ in redox esterification of cinnamaldehyde with benzyl alcohol ${ }^{a}$.

\begin{tabular}{cccccc}
\hline Run & $\begin{array}{c}\text { Reaction Time } \\
{[\mathbf{h}]}\end{array}$ & $\begin{array}{c}\text { TOF } \\
{\left[\mathbf{h}^{-\mathbf{1}} \mathbf{]}^{\boldsymbol{b}}\right.}\end{array}$ & $\begin{array}{c}\text { Isolated } \\
\text { Yield [\%] }\end{array}$ & $\begin{array}{c}\text { GC Purity } \\
{[\%]}\end{array}$ & $\begin{array}{c}\text { Catalyst } \\
\text { Recovery [\%] }^{c}\end{array}$ \\
\hline $1^{d}$ & 3 & 3.3 & 79 & 93 & 77 \\
2 & 2 & 5.0 & 73 & 97 & 89 \\
3 & 1.5 & 6.7 & 68 & 97 & 95 \\
4 & 1 & 10 & 73 & 98 & 92 \\
5 & 1 & 10 & 72 & 98 & 95 \\
6 & 1 & 10 & 73 & 98 & 92 \\
\hline
\end{tabular}

${ }^{a}$ Conditions: precatalyst loading $2.5 \mathrm{~mol} \%$ (10 mol\% with respect to active groups), $15 \mathrm{~mol} \%$ DBU, 2 equiv of benzyl alcohol +2 equiv of tert-butyl alcohol, $100{ }^{\circ} \mathrm{C} ;{ }^{b}$ average value calculated from time to full conversion; ${ }^{c}$ based on the weight of the isolated catalyst after nanofiltration; ${ }^{d} 4$ equiv of benzyl alcohol, without tertbutyl alcohol.

\section{Materials and Methods}

\subsection{General Remarks}

All experiments were carried out in anhydrous conditions under an inert atmosphere of argon or nitrogen, using standard Schlenk techniques, unless otherwise stated. Solvents were dried by usual procedures, then distilled and kept under argon. $\mathrm{CDCl}_{3}$ and DMSO- $d_{6}$ were dried over molecular sieves. Starting iodopropyl terminated dendrimers $\mathbf{G}_{\mathbf{m}}(\mathbf{P r I})_{\mathbf{n}}$ were prepared as described previously [41]. All other used chemicals were commercial products and were used without further purification. 
NMR spectra were measured on Bruker Avance $400\left({ }^{1} \mathrm{H}\right.$ at $400.1 \mathrm{MHz} ;{ }^{13} \mathrm{C}$ at $100.6 \mathrm{MHz}$; ${ }^{29} \mathrm{Si}\left\{{ }^{1} \mathrm{H}\right\}$ (inept technique) at $79.5 \mathrm{MHz}$ ) at $25{ }^{\circ} \mathrm{C} .{ }^{1} \mathrm{H}$ and ${ }^{13} \mathrm{C}$ NMR signals of prepared compounds were assigned to corresponding atoms utilizing HSQC, COSY and HMBS 2D NMR correlation spectra. ${ }^{1} \mathrm{H}$ and ${ }^{13} \mathrm{C}$ chemical shifts $(\delta / \mathrm{ppm})$ are given relative to solvent signals $\left(\delta_{\mathrm{H}} / \delta_{\mathrm{C}}\right.$ : DMSO- $\left.d_{6} 2.50 / 39.52\right) ;{ }^{29} \mathrm{Si}$ spectra were referenced to external standard hexamethyldisilane $(-19.87 \mathrm{ppm})$.

HRMS spectra were measured with Bruker MicrOTOF-QIII instrument in $\mathrm{ESI}^{+} / \mathrm{ESI}^{-}$ mode (80-3000/30-1000 $\mathrm{m} / \mathrm{z}$, calibrated by sodium formate).

GC/FID and GC/MS analyses were performed on Agilent 6890 gas chromatograph equipped with DB-5MS column (30 m_0.25 mm_0.25 mm). Injector and detector temperatures were set at $260^{\circ} \mathrm{C}$ and $300^{\circ} \mathrm{C}$, respectively. Helium was used as a carrier gas at a flow rate $1.61 \mathrm{~mL} / \mathrm{min}$. Oven temperature was set at $50{ }^{\circ} \mathrm{C}$ for $3 \mathrm{~min}$ and then programmed to $290{ }^{\circ} \mathrm{C}$ at a rate $10^{\circ} \mathrm{C} / \mathrm{min}$. Quantitative data were calculated using Agilent MSD Chemstation D.02 from the FID peak areas assuming a linear response for the analytes and the internal standard dioctyl phthalate and applying relative response factors calculated from the molecular formula according to previously published method [50]. In the case of cinnamaldehyde, benzyl 3-phenylpropanoate and benzyl cinnamate the results were corrected with respect to experimentally determined calibration curves relative to dioctyl phthalate.

\subsection{Synthesis of Model Imidazolium Salts and Poly(imidazolium) Carbosilane Dendrimers}

General procedure. To a solution of the starting iodopropyl derivative $\mathbf{G}_{\mathbf{m}}(\mathbf{P r I})_{\mathbf{n}}$ $(1.0 \mathrm{mmol})$ in acetonitrile $(15 \mathrm{~mL})$ a solution of a given imidazole (1.3 eq. for each iodide) in acetonitrile was added at $0{ }^{\circ} \mathrm{C}$. The reaction mixture was then stirred at $70{ }^{\circ} \mathrm{C}$ for $48 \mathrm{~h}$. The solvent was removed on the rotary evaporator and toluene $(6 \mathrm{~mL})$ was added to the residue to wash out the unreacted imidazole. The mixture was stirred at $80^{\circ} \mathrm{C}$ for $6 \mathrm{~h}$, let to cool down and decanted at room temperature. The residue was dried under vacuum to afford the product.

1-Methyl-3-[3-(butyldimethylsilyl)]propylimidazolium iodide $\left(\mathrm{G}_{0} \mathrm{MeImI}\right)$. The compound was prepared from 3-(butyldimethylsilyl)propyl iodide $(1 \mathrm{~g}, 3.52 \mathrm{mmol})$ and 1-methylimidazole (0.35 g, $4.22 \mathrm{mmol})$. Yield: $1.2 \mathrm{~g}$ (3.31 mmol, 94\%) of a yellow liquid. ${ }^{1} \mathrm{H}$ NMR (DMSO$d_{6}, 400 \mathrm{MHz}, \mathrm{H}-\mathrm{H}$ COSY): $\delta-0.04(\mathrm{~s}, 6 \mathrm{H}, \mathrm{SiMe} 2), 0.39-0.43\left(\mathrm{~m}, 2 \mathrm{H}, \mathrm{CH}_{2} \mathrm{CH}_{2} \mathrm{CH}_{2} \mathrm{~N}\right)$, 0.46-0.50 (m, 2H, $\left.\mathrm{CH}_{2} \mathrm{CH}_{2} \mathrm{CH}_{2} \mathrm{CH}_{3}\right), 0.85\left(\mathrm{t}, J=7.0 \mathrm{~Hz}, 3 \mathrm{H}, \mathrm{CH}_{3} \mathrm{CH}_{2}\right), 1.18-1.32(\mathrm{~m}$, $\left.4 \mathrm{H}, \mathrm{CH}_{2} \mathrm{CH}_{2} \mathrm{CH}_{3}\right), 1.71-1.79\left(\mathrm{~m}, 2 \mathrm{H}, \mathrm{CH}_{2} \mathrm{CH}_{2} \mathrm{~N}\right), 3.85$ (s, 3H, NMe), 4.12 (t, J = 7.2 Hz, $\left.2 \mathrm{H}, \mathrm{CH}_{2} \mathrm{~N}\right), 7.70,7.77,9.11(3 \times \mathrm{t}, J=1.7 \mathrm{~Hz}, 3 \times 1 \mathrm{H}, \mathrm{CH}) .{ }^{13} \mathrm{C}\left\{{ }^{1} \mathrm{H}\right\}$ NMR (DMSO- $d_{6}$, $\left.101 \mathrm{MHz}, \mathrm{HSQC}, \mathrm{HMBC}): \delta-3.5(\mathrm{SiMe})_{2}\right), 11.1\left(\mathrm{SiCH}_{2} \mathrm{CH}_{2} \mathrm{CH}_{2} \mathrm{~N}\right), 13.7\left(\mathrm{CH}_{2} \mathrm{CH}_{3}\right), 14.2$ $\left(\mathrm{SiCH}_{2} \mathrm{CH}_{2} \mathrm{CH}_{2} \mathrm{CH}_{3}\right), 24.5\left(\mathrm{CH}_{2} \mathrm{CH}_{2} \mathrm{CH}_{2} \mathrm{~N}\right), 25.5,26.0\left(\mathrm{CH}_{2} \mathrm{CH}_{2} \mathrm{CH}_{3}\right), 35.8(\mathrm{NMe}), 51.6$ $\left(\mathrm{CH}_{2} \mathrm{~N}\right), 122.2,123.6,136.5(3 \times \mathrm{CH}) .{ }^{29} \mathrm{Si}\left\{{ }^{1} \mathrm{H}\right\} \mathrm{NMR}\left(\mathrm{DMSO}-d_{6}, 80 \mathrm{MHz}\right): \delta 2.87 . \mathrm{HRMS}$ (ESI+) $\left[\mathrm{C}_{13} \mathrm{H}_{27} \mathrm{~N}_{2} \mathrm{Si}\right]^{+}$calc. $239.1938[\mathrm{M}-\mathrm{I}]^{+}$, found $239.1943(100 \%)$.

1-Isopropyl-3-[3-(butyldimethylsilyl)]propylimidazolium iodide $\left(\mathrm{G}_{0} \mathrm{iPrImI}\right)$. The compound was prepared from 3-(butyldimethylsilyl)propyl iodide $(0.21 \mathrm{~g}, 0.74 \mathrm{mmol})$ and 1-isopropylimidazole $(0.11 \mathrm{~g}, 1.00 \mathrm{mmol})$. Yield: $0.25 \mathrm{~g}(0.64 \mathrm{mmol}, 87 \%)$ of a brownish yellow viscous liquid. ${ }^{1} \mathrm{H}$ NMR (DMSO- $d_{6}, 400 \mathrm{MHz}, \mathrm{H}-\mathrm{H}$ COSY): $\delta-0.05(\mathrm{~s}, 6 \mathrm{H}, \mathrm{SiMe} 2)$, 0.39-0.45 (m, 2H, CH $\left.\mathrm{CH}_{2} \mathrm{CH}_{2} \mathrm{~N}\right), 0.46-0.50\left(\mathrm{~m}, 2 \mathrm{H}, \mathrm{CH}_{2} \mathrm{CH}_{2} \mathrm{CH}_{2} \mathrm{CH}_{3}\right), 0.84$ (t, J = 7.0 Hz, $\left.3 \mathrm{H}, \mathrm{CH}_{3} \mathrm{CH}_{2}\right), 1.19-1.30\left(\mathrm{~m}, 4 \mathrm{H}, \mathrm{CH}_{2} \mathrm{CH}_{2} \mathrm{CH}_{3}\right), 1.47$ (d, J = 7.0 Hz, 6H, CHMe $), 1.74-1.82$ $\left(\mathrm{m}, 2 \mathrm{H}, \mathrm{CH}_{2} \mathrm{CH}_{2} \mathrm{~N}\right), 4.12\left(\mathrm{t}, J=7.2 \mathrm{~Hz}, 2 \mathrm{H}, \mathrm{CH}_{2} \mathrm{~N}\right), 4.65$ (hept, $J=7.0 \mathrm{~Hz}, 1 \mathrm{H}, \mathrm{CHMe}$ ), 7.84, 7.93, $9.31(3 \times \mathrm{t}, J=1.7 \mathrm{~Hz}, 3 \times 1 \mathrm{H}, \mathrm{CH}) .{ }^{13} \mathrm{C}\left\{{ }^{1} \mathrm{H}\right\}$ NMR (DMSO-d $d_{6}, 101 \mathrm{MHz}, \mathrm{HSQC}$, $\mathrm{HMBC}): \delta-3.5(\mathrm{SiMe}), 11.1\left(\mathrm{CH}_{2} \mathrm{CH}_{2} \mathrm{CH}_{2} \mathrm{~N}\right), 13.6\left(\mathrm{CH}_{2} \mathrm{CH}_{3}\right), 14.1\left(\mathrm{CH}_{2} \mathrm{CH}_{2} \mathrm{CH}_{2} \mathrm{CH}_{3}\right)$, $22.3\left(\mathrm{CHMe}_{2}\right), 24.3\left(\mathrm{CH}_{2} \mathrm{CH}_{2} \mathrm{~N}\right), 25.5,25.9\left(\mathrm{CH}_{2} \mathrm{CH}_{2} \mathrm{CH}_{3}\right), 51.6\left(\mathrm{CH}_{2} \mathrm{~N}\right), 52.1\left(\mathrm{CHMe}_{2}\right)$, $120.5,122.4,134.7(3 \times \mathrm{CH}) .{ }^{29} \mathrm{Si}\left\{{ }^{1} \mathrm{H}\right\} \mathrm{NMR}\left(\mathrm{DMSO}-d_{6}, 80 \mathrm{MHz}\right): \delta 2.86 . \mathrm{HRMS}(\mathrm{ESI}+)$ $\left[\mathrm{C}_{15} \mathrm{H}_{31} \mathrm{~N}_{2} \mathrm{Si}\right]^{+}$calc. $267.2251[\mathrm{M}-\mathrm{I}]^{+}$, found $267.2256(100 \%) ;(\mathrm{ESI}-) \mathrm{I}^{-}$calc. 126.9039, found $126.9045(100 \%)$.

1-(2,6-diisopropylphenyl)-3-[3-(butyldimethylsilyl)]propylimidazolium iodide ( $\mathrm{G}_{0}$ DippImI). The compound was prepared from 3-(butyldimethylsilyl)propyl iodide $(0.11 \mathrm{~g}$, $0.38 \mathrm{mmol})$ 
and 1-(2,6-diisopropylphenyl)imidazole (0.12 g, $0.52 \mathrm{mmol})$. Yield: $0.18 \mathrm{~g}$ (0.35 mmol, 93\%) of a yellow solid. ${ }^{1} \mathrm{H}$ NMR (DMSO- $d_{6}, 400 \mathrm{MHz}, \mathrm{H}-\mathrm{H}$ COSY): $\delta-0.03$ (s, 6H, SiMe 2 ), 0.30$0.34\left(\mathrm{~m}, 2 \mathrm{H}, \mathrm{CH}_{2} \mathrm{CH}_{2} \mathrm{CH}_{2} \mathrm{~N}\right), 0.47-0.51\left(\mathrm{~m}, 2 \mathrm{H}, \mathrm{CH}_{2} \mathrm{CH}_{2} \mathrm{CH}_{2} \mathrm{CH}_{3}\right), 0.85(\mathrm{t}, J=7.1 \mathrm{~Hz}, 3 \mathrm{H}$, $\left.\mathrm{CH}_{3} \mathrm{CH}_{2}\right), 1.14\left(\mathrm{t}, \mathrm{J}=6.6 \mathrm{~Hz}, 12 \mathrm{H}, \mathrm{Me}{ }_{2} \mathrm{CH}\right), 1.20-1.32\left(\mathrm{~m}, 4 \mathrm{H}, \mathrm{CH}_{2} \mathrm{CH}_{2} \mathrm{CH}_{3}\right), 1.83-1.90(\mathrm{~m}$, $2 \mathrm{H}, \mathrm{CH}_{2} \mathrm{CH}_{2} \mathrm{~N}$ ), 2.25 (hept, $\left.J=6.6 \mathrm{~Hz}, 2 \mathrm{H}, \mathrm{Me}_{2} \mathrm{CH}\right), 4.28\left(\mathrm{t}, J=6.4 \mathrm{~Hz}, 2 \mathrm{H}, \mathrm{CH}_{2} \mathrm{~N}\right), 7.47(\mathrm{~d}$, $\left.J=7.8 \mathrm{~Hz}, 2 \mathrm{H}, \mathrm{CH}_{P h}\right), 7.64\left(\mathrm{t}, J=7.8 \mathrm{~Hz}, 1 \mathrm{H}, \mathrm{CH}_{P h}\right), 8.13,8.15,9.62(3 \times \mathrm{t}, J=1.5 \mathrm{~Hz}, 3 \times 1 \mathrm{H}$, $\left.\mathrm{CH}_{\text {Im }}\right) .{ }^{13} \mathrm{C}\left\{{ }^{1} \mathrm{H}\right\}$ NMR (DMSO- $\left.d_{6}, 101 \mathrm{MHz}, \mathrm{HSQC}\right): \delta-3.6(\mathrm{SiMe}), 10.7\left(\mathrm{CH}_{2} \mathrm{CH}_{2} \mathrm{CH}_{2} \mathrm{~N}\right)$, $13.7\left(\mathrm{CH}_{2} \mathrm{CH}_{3}\right), 14.2\left(\mathrm{CH}_{2} \mathrm{CH}_{2} \mathrm{CH}_{2} \mathrm{CH}_{3}\right), 23.7,23.8\left(\mathrm{CHMe}_{2}\right), 24.0\left(\mathrm{CH}_{2} \mathrm{CH}_{2} \mathrm{~N}\right), 25.5,26.0$ $\left(\mathrm{CH}_{2} \mathrm{CH}_{2} \mathrm{CH}_{3}\right), 28.1(\mathrm{CHMe}), 52.2\left(\mathrm{CH}_{2} \mathrm{~N}\right), 123.4\left(\mathrm{CH}_{I m}\right), 124.4\left(2 \mathrm{CH}_{P h}\right), 125.3\left(\mathrm{CH}_{I m}\right), 130.5$

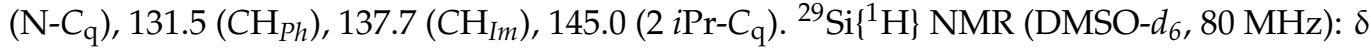
2.86. HRMS (ESI+) $\left[\mathrm{C}_{24} \mathrm{H}_{41} \mathrm{~N}_{2} \mathrm{Si}\right]^{+}$calc. $385.3033[\mathrm{M}-\mathrm{I}]^{+}$, found $385.3039(100 \%)$; (ESI-) $\mathrm{I}^{-}$ calc. 126.9039 , found $126.9022(100 \%)$.

Dendrimer $\mathrm{G}_{\mathbf{1}}(\mathbf{M e I m I})_{4}$. The compound was prepared from dendrimer $\mathbf{G}_{\mathbf{1}}(\mathbf{P r I})_{4}$ $(1.20 \mathrm{~g}, 1.09 \mathrm{mmol})$ and 1-methylimidazole $(0.43 \mathrm{~g}, 5.21 \mathrm{mmol})$. Yield: $1.51 \mathrm{~g}$ (1.05 mmol, $97 \%$ ) of a yellow liquid. ${ }^{1} \mathrm{H}$ NMR (DMSO- $d_{6}, 400 \mathrm{MHz}, \mathrm{H}-\mathrm{H}$ COSY): $\delta-0.05$ (s, 24H, SiMe 2 ), 0.38-0.42 (m, 8H, $\left.\mathrm{CH}_{2} \mathrm{CH}_{2} \mathrm{CH}_{2} \mathrm{~N}\right), 0.50-0.56\left(\mathrm{~m}, 16 \mathrm{H}, \mathrm{Si}^{0} \mathrm{CH}_{2} \mathrm{CH}_{2} \mathrm{CH}_{2}\right), 1.26-1.33(\mathrm{~m}, 8 \mathrm{H}$, $\left.\mathrm{Si}^{0} \mathrm{CH}_{2} \mathrm{CH}_{2}\right), 1.70-1.78\left(\mathrm{~m}, 8 \mathrm{H}, \mathrm{CH}_{2} \mathrm{CH}_{2} \mathrm{~N}\right), 3.86(\mathrm{~s}, 12 \mathrm{H}, \mathrm{NMe}), 4.11(\mathrm{t}, J=7.2 \mathrm{~Hz}, 8 \mathrm{H}$, $\left.\mathrm{CH}_{2} \mathrm{~N}\right), 7.80,7.90,9.13(3 \times \mathrm{t}, J=1.8 \mathrm{~Hz}, 3 \times 4 \mathrm{H}, \mathrm{CH}) .{ }^{13} \mathrm{C}\left\{{ }^{1} \mathrm{H}\right\} \mathrm{NMR}\left(\mathrm{DMSO}-d_{6}, 101 \mathrm{MHz}\right.$, HSQC, HMBC): $\delta-3.5\left(\mathrm{SiMe}_{2}\right), 11.3\left(\mathrm{CH}_{2} \mathrm{CH}_{2} \mathrm{CH}_{2} \mathrm{~N}\right), 16.9\left(\mathrm{Si}^{0} \mathrm{CH}_{2}\right), 18.1\left(\mathrm{Si}^{0} \mathrm{CH}_{2} \mathrm{CH}_{2}\right), 19.3$ $\left(\mathrm{Si}^{0} \mathrm{CH}_{2} \mathrm{CH}_{2} \mathrm{CH}_{2}\right), 24.4\left(\mathrm{CH}_{2} \mathrm{CH}_{2} \mathrm{~N}\right), 35.8(\mathrm{NMe}), 51.5\left(\mathrm{CH}_{2} \mathrm{~N}\right), 122.2,123.5,136.4(3 \times \mathrm{CH})$. ${ }^{29} \mathrm{Si}\left\{{ }^{1} \mathrm{H}\right\}$ NMR (DMSO- $\left.d_{6}, 80 \mathrm{MHz}\right): \delta 0.73\left(\mathrm{Si}^{0}\right), 2.25\left(\mathrm{Si}^{1}\right)$. HRMS (ESI+) $\left[\mathrm{C}_{48} \mathrm{H}_{96} \mathrm{~N}_{8} \mathrm{Si}_{5} \mathrm{I}_{3}\right]^{+}$ calc. $1305.3733[\mathrm{M}-\mathrm{I}]^{+}$, found $1305.3734(100 \%) ;\left[\mathrm{C}_{48} \mathrm{H}_{96} \mathrm{~N}_{8} \mathrm{Si}_{5} \mathrm{I}_{2}\right]^{2+}$ calc. $589.2341[\mathrm{M}-2 \mathrm{I}]^{2+}$, found $589.2348(100 \%) ;\left[\mathrm{C}_{48} \mathrm{H}_{96} \mathrm{~N}_{8} \mathrm{Si}_{5} \mathrm{I}\right]^{3+}$ calc. $350.5211[\mathrm{M}-3 \mathrm{I}]^{3+}$, found $350.5212(100 \%)$; $\left[\mathrm{C}_{48} \mathrm{H}_{96} \mathrm{~N}_{8} \mathrm{Si}_{5}\right]^{4+}$ calc. $231.1645[\mathrm{M}-4 \mathrm{I}]^{4+}$, found $231.1645(100 \%)$.

Dendrimer $\mathbf{G}_{\mathbf{2}}(\mathbf{M e I m I})_{8}$. The compound was prepared from dendrimer $\mathbf{G}_{\mathbf{2}}(\mathbf{P r I})_{\mathbf{8}}$ $(1.00 \mathrm{~g}, 0.40 \mathrm{mmol})$ and 1-methylimidazole $(0.36 \mathrm{~g}, 4.40 \mathrm{mmol})$. Yield: $1.17 \mathrm{~g}(0.37 \mathrm{mmol}$, $93 \%$ ) of a pale yellow waxy solid. ${ }^{1} \mathrm{H}$ NMR (DMSO- $d_{6}, 400 \mathrm{MHz}, \mathrm{H}-\mathrm{H}$ COSY): $\delta-0.11$ (s, $12 \mathrm{H}, \mathrm{SiMe}),-0.06$ (s, 48H, SiMe $), 0.38-0.42\left(\mathrm{~m}, 16 \mathrm{H}, \mathrm{CH}_{2} \mathrm{CH}_{2} \mathrm{CH}_{2} \mathrm{~N}\right), 0.49-0.55$ (m, $\left.48 \mathrm{H}, \mathrm{Si}^{1} \mathrm{CH}_{2} \mathrm{CH}_{2} \mathrm{CH}_{2}\right), 1.24-1.32\left(\mathrm{~m}, 24 \mathrm{H}, \mathrm{Si}^{1} \mathrm{CH}_{2} \mathrm{CH}_{2}\right), 1.70-1.78\left(\mathrm{~m}, 16 \mathrm{H}, \mathrm{CH}_{2} \mathrm{CH}_{2} \mathrm{~N}\right)$, 3.86 (brs, 24H, NMe), $4.12\left(\mathrm{t}, J=7.2 \mathrm{~Hz}, 16 \mathrm{H}, \mathrm{CH}_{2} \mathrm{~N}\right), 7.72,7.77,9.15(3 \times \mathrm{m}, 3 \times 8 \mathrm{H}$, $\mathrm{CH}) .{ }^{13} \mathrm{C}\left\{{ }^{1} \mathrm{H}\right\}$ NMR (DMSO- $\left.d_{6}, 101 \mathrm{MHz}, \mathrm{HSQC}, \mathrm{HMBC}\right): \delta-4.9(\mathrm{SiMe}),-3.5(\mathrm{SiMe}), 11.3$ $\left(\mathrm{CH}_{2} \mathrm{CH}_{2} \mathrm{CH}_{2} \mathrm{~N}\right), 17.1\left(\mathrm{Si}^{0} \mathrm{CH}_{2}\right), 18.0\left(\mathrm{Si}^{1} \mathrm{CH}_{2} \mathrm{CH}_{2} \mathrm{CH}_{2} \mathrm{Si}^{2}\right)$, overlapped $\left(\mathrm{Si}^{0} \mathrm{CH}_{2} \mathrm{CH}_{2}\right), 18.2$ $\left(\mathrm{Si}^{1} \mathrm{CH}_{2} \mathrm{CH}_{2} \mathrm{CH}_{2} \mathrm{Si}^{2}\right), 18.5\left(\mathrm{Si}^{0} \mathrm{CH}_{2} \mathrm{CH}_{2} \mathrm{CH}_{2}\right), 19.3\left(\mathrm{Si}^{1} \mathrm{CH}_{2} \mathrm{CH}_{2} \mathrm{CH}_{2} \mathrm{Si}^{2}\right), 24.4\left(\mathrm{CH}_{2} \mathrm{CH}_{2} \mathrm{~N}\right)$, $35.8(\mathrm{NMe}), 51.5\left(\mathrm{CH}_{2} \mathrm{~N}\right), 122.2,123.6,136.5(3 \times \mathrm{CH}) .{ }^{29} \mathrm{Si}\left\{{ }^{1} \mathrm{H}\right\} \mathrm{NMR}\left(\mathrm{DMSO}-d_{6}, 80 \mathrm{MHz}\right)$ : $\delta 0.82\left(\mathrm{Si}^{0}\right) ; 1.06\left(\mathrm{Si}^{1}\right), 2.22\left(\mathrm{Si}^{2}\right)$. HRMS (ESI+) $\left[\mathrm{C}_{112} \mathrm{H}_{228} \mathrm{~N}_{16} \mathrm{Si}_{13} \mathrm{I}_{7}\right]^{+}$calc. 3051.8667 $[\mathrm{M}-\mathrm{I}]^{+}$, found $3051.8731(100 \%) ;\left[\mathrm{C}_{112} \mathrm{H}_{228} \mathrm{~N}_{16} \mathrm{Si}_{13} \mathrm{I}_{6}\right]^{2+}$ calc. $1462.4808[\mathrm{M}-2 \mathrm{I}]^{2+}$, found $1462.4803(100 \%) ;\left[\mathrm{C}_{112} \mathrm{H}_{228} \mathrm{~N}_{16} \mathrm{Si}_{13} \mathrm{I}_{5}\right]^{3+}$ calc. $932.6855[\mathrm{M}-3 \mathrm{I}]^{3+}$, found $932.6856(100 \%)$; $\left[\mathrm{C}_{112} \mathrm{H}_{228} \mathrm{~N}_{16} \mathrm{Si}_{13} \mathrm{I}_{4}\right]^{4+}$ calc. $667.7879[\mathrm{M}-4 \mathrm{I}]^{4+}$, found $667.7897(100 \%) ;\left[\mathrm{C}_{112} \mathrm{H}_{228} \mathrm{~N}_{16} \mathrm{Si}_{13} \mathrm{I}_{3}\right]^{5+}$ calc. $508.8493[\mathrm{M}-5 \mathrm{I}]^{5+}$, found $508.8498(100 \%)$.

Dendrimer $\mathbf{G}_{3}(\mathbf{M e I m I})_{16}$. The compound was prepared from dendrimer $\mathbf{G}_{\mathbf{3}}(\mathbf{P r I})_{16}$ $(0.65 \mathrm{~g}, 0.12 \mathrm{mmol})$ and 1-methylimidazole $(0.24 \mathrm{~g}, 2.90 \mathrm{mmol})$. Yield: $0.74 \mathrm{~g}(0.11 \mathrm{mmol}$, $92 \%$ ) of a yellow waxy solid. ${ }^{1} \mathrm{H}$ NMR (DMSO- $d_{6}, 400 \mathrm{MHz}, \mathrm{H}-\mathrm{H}$ COSY): $\delta-0.13(\mathrm{~s}, 12 \mathrm{H}$, $\left.\mathrm{Si}^{1} \mathrm{Me}\right),-0.11\left(\mathrm{~s}, 24 \mathrm{H}, \mathrm{Si}^{2} \mathrm{Me}\right),-0.06(\mathrm{~s}, 96 \mathrm{H}, \mathrm{SiMe}), 0.39-0.43\left(\mathrm{~m}, 32 \mathrm{H}, \mathrm{CH}_{2} \mathrm{CH}_{2} \mathrm{CH}_{2} \mathrm{~N}\right)$, 0.49-0.55 (m, 112H, SiCH $\left.\mathrm{CH}_{2} \mathrm{CH}_{2} \mathrm{Si}\right), 1.24-1.32$ (m, 56H, $\left.\mathrm{SiCH}_{2} \mathrm{CH}_{2} \mathrm{CH}_{2} \mathrm{Si}\right), 1.71-1.79$ (m, $32 \mathrm{H}, \mathrm{CH}_{2} \mathrm{CH}_{2} \mathrm{~N}$ ), 3.87 (s, 48H, NMe), $4.13\left(\mathrm{t}, J=7.3 \mathrm{~Hz}, 32 \mathrm{H}, \mathrm{CH}_{2} \mathrm{~N}\right), 7.73,7.80,9.19$ $(3 \times$ brs, $3 \times 16 \mathrm{H}, \mathrm{CH}) \cdot{ }^{13} \mathrm{C}\left\{{ }^{1} \mathrm{H}\right\}$ NMR $\left(\mathrm{DMSO}-d_{6}, 101 \mathrm{MHz}, \mathrm{HSQC}, \mathrm{HMBC}\right): \delta-4.9$ $\left.\left(\mathrm{Si}^{1,2} \mathrm{Me}\right),-3.5(\mathrm{SiMe})_{2}\right), 11.3\left(\mathrm{CH}_{2} \mathrm{CH}_{2} \mathrm{CH}_{2} \mathrm{~N}\right), 17.1\left(\mathrm{Si}^{0} \mathrm{CH}_{2}\right), 18.0\left(\mathrm{Si}^{2} \mathrm{CH}_{2} \mathrm{CH}_{2} \mathrm{CH}_{2} \mathrm{Si}^{3}\right)$, 18.1, $18.4\left(\mathrm{Si}^{1} \mathrm{CH}_{2} \mathrm{CH}_{2} \mathrm{CH}_{2} \mathrm{Si}^{2}\right)$, overlapped $\left(\mathrm{Si}^{0} \mathrm{CH}_{2} \mathrm{CH}_{2}\right), 18.2\left(\mathrm{Si}^{2} \mathrm{CH}_{2} \mathrm{CH}_{2} \mathrm{CH}_{2} \mathrm{Si}^{3}\right), 18.6$ $\left(\mathrm{Si}^{0} \mathrm{CH}_{2} \mathrm{CH}_{2} \mathrm{CH}_{2}\right), 19.3\left(\mathrm{Si}^{2} \mathrm{CH}_{2} \mathrm{CH}_{2} \mathrm{CH}_{2} \mathrm{Si}^{3}\right), 24.4\left(\mathrm{CH}_{2} \mathrm{CH}_{2} \mathrm{~N}\right), 35.9(\mathrm{NMe}), 51.5\left(\mathrm{CH}_{2} \mathrm{~N}\right)$, 122.2, 123.5, $136.4(3 \times \mathrm{CH}) .{ }^{29} \mathrm{Si}\left\{{ }^{1} \mathrm{H}\right\} \mathrm{NMR}\left(\mathrm{DMSO}-d_{6}, 80 \mathrm{MHz}\right): \delta 0.77\left(\mathrm{Si}^{0}\right) ; 1.04\left(\mathrm{Si}^{1,2}\right), 2.20$ $\left(\mathrm{Si}^{3}\right)$. HRMS (ESI+) $\left[\mathrm{C}_{240} \mathrm{H}_{492} \mathrm{~N}_{32} \mathrm{Si}_{29} \mathrm{I}_{15}\right]^{+}$calc. $6543.8509[\mathrm{M}-\mathrm{I}]^{+},\left[\mathrm{C}_{240} \mathrm{H}_{492} \mathrm{~N}_{32} \mathrm{Si}_{29} \mathrm{I}_{14}\right]^{2+}$ calc. $3208.4729[\mathrm{M}-2 \mathrm{I}]^{2+}$, both out of range; $\left[\mathrm{C}_{240} \mathrm{H}_{492} \mathrm{~N}_{32} \mathrm{Si}_{29} \mathrm{I}_{13}\right]^{3+}$ calc. 2096.6803 [M$3 \mathrm{I}]^{3+}$, found $2096.7014(100 \%) ;\left[\mathrm{C}_{240} \mathrm{H}_{492} \mathrm{~N}_{32} \mathrm{Si}_{29} \mathrm{I}_{12}\right]^{4+}$ calc. $1540.7840[\mathrm{M}-4 \mathrm{I}]^{4+}$, found $1540.7580(100 \%) ;\left[\mathrm{C}_{240} \mathrm{H}_{492} \mathrm{~N}_{32} \mathrm{Si}_{29} \mathrm{I}_{11}\right]^{5+}$ calc. $1207.2461[\mathrm{M}-5 \mathrm{I}]^{5+}$, found $1207.2463(100 \%)$; 
$\left[\mathrm{C}_{240} \mathrm{H}_{492} \mathrm{~N}_{32} \mathrm{Si}_{29} \mathrm{I}_{10}\right]^{6+}$ calc. 984.8876 [M-6I] ${ }^{6+}$, found $984.8814(100 \%) ;\left[\mathrm{C}_{240} \mathrm{H}_{492} \mathrm{~N}_{32} \mathrm{Si}_{29} \mathrm{I}_{9}\right]^{7+}$ calc. $826.0601[\mathrm{M}-7 \mathrm{I}]^{7+}$, found $826.0625(100 \%) ;\left[\mathrm{C}_{240} \mathrm{H}_{492} \mathrm{~N}_{32} \mathrm{Si}_{29} \mathrm{I}_{8}\right]^{8+}$ calc. $706.9394[\mathrm{M}-$ 8I ${ }^{8+}$, found $706.9372(100 \%) ;\left[\mathrm{C}_{240} \mathrm{H}_{492} \mathrm{~N}_{32} \mathrm{Si}_{29} \mathrm{I}_{7}\right]^{9+}$ calc. $614.2900[\mathrm{M}-9 \mathrm{I}]^{9+}$, found 614.2889 (100\%); $\left[\mathrm{C}_{240} \mathrm{H}_{492} \mathrm{~N}_{32} \mathrm{Si}_{29} \mathrm{I}_{6}\right]^{10+}$ calc. $540.1706[\mathrm{M}-10 \mathrm{I}]^{10+}$, found $540.1754(100 \%)$.

Dendrimer $\mathrm{G}_{\mathbf{1}}(\mathrm{iPrImI})_{4}$. The compound was prepared from dendrimer $\mathrm{G}_{\mathbf{1}}(\operatorname{PrI})_{4}$ $(0.35 \mathrm{~g}, 0.32 \mathrm{mmol})$ and 1-isopropylimidazole $(0.19 \mathrm{~g}, 1.72 \mathrm{mmol})$. Yield: $0.36 \mathrm{~g}(0.23 \mathrm{mmol}$, $73 \%$ ) of a brownish yellow viscous liquid. ${ }^{1} \mathrm{H}$ NMR (DMSO- $d_{6}, 400 \mathrm{MHz}, \mathrm{H}-\mathrm{H}$ COSY): $\delta$ $-0.05\left(\mathrm{~s}, 24 \mathrm{H}, \mathrm{SiMe} e_{2}\right), 0.38-0.42\left(\mathrm{~m}, 8 \mathrm{H}, \mathrm{CH}_{2} \mathrm{CH}_{2} \mathrm{CH}_{2} \mathrm{~N}\right), 0.50-0.56\left(\mathrm{~m}, 16 \mathrm{H}, \mathrm{SiCH}_{2} \mathrm{CH}_{2} \mathrm{CH}_{2} \mathrm{Si}\right)$, 1.26-1.32 (m, 8H, Si $\left.{ }^{0} \mathrm{CH}_{2} \mathrm{CH}_{2}\right), 1.47(\mathrm{~d}, J=6.7 \mathrm{~Hz}, 24 \mathrm{H}, \mathrm{CHMe} 2), 1.72-1.80(\mathrm{~m}, 8 \mathrm{H}$, $\left.\mathrm{CH}_{2} \mathrm{CH}_{2} \mathrm{~N}\right), 4.09\left(\mathrm{t}, J=7.3 \mathrm{~Hz}, 8 \mathrm{H}, \mathrm{CH}_{2} \mathrm{~N}\right), 4.62$ (hept, $\left.J=6.7 \mathrm{~Hz}, 4 \mathrm{H}, \mathrm{CHMe}_{2}\right), 7.80$, $7.90(2 \times \mathrm{t}, J=1.7 \mathrm{~Hz}, 2 \times 4 \mathrm{H}, \mathrm{CH}), 9.24(\mathrm{brs}, 4 \mathrm{H}, \mathrm{CH}) .{ }^{13} \mathrm{C}\left\{{ }^{1} \mathrm{H}\right\}$ NMR (DMSO-d $d_{6}$, $101 \mathrm{MHz}, \mathrm{HSQC}): \delta-3.5(\mathrm{SiMe}), 11.5\left(\mathrm{CH}_{2} \mathrm{CH}_{2} \mathrm{CH}_{2} \mathrm{~N}\right), 17.0\left(\mathrm{Si}^{0} \mathrm{CH}_{2}\right), 18.2\left(\mathrm{Si}^{0} \mathrm{CH}_{2} \mathrm{CH}_{2}\right)$, $19.4\left(\mathrm{Si}^{0} \mathrm{CH}_{2} \mathrm{CH}_{2} \mathrm{CH}_{2}\right), 22.4(\mathrm{CHMe} 2), 24.4\left(\mathrm{CH}_{2} \mathrm{CH}_{2} \mathrm{~N}\right), 51.7\left(\mathrm{CH}_{2} \mathrm{~N}\right), 52.3\left(\mathrm{CHMe}_{2}\right)$, 120.6, $122.5(2 \times \mathrm{CH})$, (from HSQC) $134.5(\mathrm{CH}) .{ }^{29} \mathrm{Si}\left\{{ }^{1} \mathrm{H}\right\} \mathrm{NMR}$ (DMSO- $\left.d_{6}, 80 \mathrm{MHz}\right): \delta 0.72\left(\mathrm{Si}^{0}\right)$, $2.25\left(\mathrm{Si}^{1}\right)$. HRMS (ESI+) $\left[\mathrm{C}_{56} \mathrm{H}_{112} \mathrm{~N}_{8} \mathrm{Si}_{5} \mathrm{I}_{3}\right]^{+}$calc. $1417.4985[\mathrm{M}-\mathrm{I}]^{+}$, found $1417.4972(100 \%)$; $\left[\mathrm{C}_{56} \mathrm{H}_{112} \mathrm{~N}_{8} \mathrm{Si}_{5} \mathrm{I}_{2}\right]^{2+}$ calc. $645.2967[\mathrm{M}-2 \mathrm{I}]^{2+}$, found $645.2965(100 \%) ;\left[\mathrm{C}_{56} \mathrm{H}_{112} \mathrm{~N}_{8} \mathrm{Si}_{5} \mathrm{I}\right]^{3+}$ calc. $387.8961[\mathrm{M}-3 \mathrm{II}]^{3+}$, found $387.8957(100 \%) ;\left[\mathrm{C}_{56} \mathrm{H}_{112} \mathrm{~N}_{8} \mathrm{Si}_{5}\right]^{4+}$ calc. $259.1958[\mathrm{M}-4 \mathrm{II}]^{4+}$, found $259.1963(100 \%)$.

Dendrimer $\mathbf{G}_{\mathbf{2}}(\mathbf{i P r I m I})_{\mathbf{8}}$. The compound was prepared from dendrimer $\mathbf{G}_{\mathbf{2}}(\mathbf{P r I})_{\mathbf{8}}$ $(0.42 \mathrm{~g}, 0.16 \mathrm{mmol})$ and 1-isopropylimidazole $(0.19 \mathrm{~g}, 1.72 \mathrm{mmol})$. Yield: $0.39 \mathrm{~g}(0.37 \mathrm{mmol}$, $69 \%$ ) of a brownish yellow viscous liquid. ${ }^{1} \mathrm{H}$ NMR (DMSO- $d_{6}, 400 \mathrm{MHz}, \mathrm{H}-\mathrm{H}$ COSY): $\delta-0.12(\mathrm{~s}, 12 \mathrm{H}, \mathrm{SiMe}),-0.06$ (s, 48H, SiMe $), 0.38-0.42\left(\mathrm{~m}, 16 \mathrm{H}, \mathrm{CH}_{2} \mathrm{CH}_{2} \mathrm{CH}_{2} \mathrm{~N}\right), 0.49-$ $0.55\left(\mathrm{~m}, 48 \mathrm{H}, \mathrm{Si}^{1} \mathrm{CH}_{2} \mathrm{CH}_{2} \mathrm{CH}_{2}\right), 1.24-1.32\left(\mathrm{~m}, 24 \mathrm{H}, \mathrm{Si}^{1} \mathrm{CH}_{2} \mathrm{CH}_{2}\right), 1.48(\mathrm{~d}, J=6.7 \mathrm{~Hz}, 48 \mathrm{H}$, $\left.\mathrm{CHMe}_{2}\right), 1.73-1.81\left(\mathrm{~m}, 16 \mathrm{H}, \mathrm{CH}_{2} \mathrm{CH}_{2} \mathrm{~N}\right), 4.11\left(\mathrm{t}, J=7.4 \mathrm{~Hz}, 16 \mathrm{H}, \mathrm{CH}_{2} \mathrm{~N}\right), 4.64$ (hept, $J=6.6 \mathrm{~Hz}, 8 \mathrm{H}, \mathrm{CHMe}), 7.83,7.93,9.30(3 \times$ brs, $\left.3 \times 8 \mathrm{H}, \mathrm{CH}) .{ }^{13} \mathrm{C}^{1}{ }^{1} \mathrm{H}\right\}$ NMR (DMSO$\left.d_{6}, 101 \mathrm{MHz}, \mathrm{HSQC}, \mathrm{HMBC}\right): \delta-4.9(\mathrm{SiMe}),-3.5(\mathrm{SiMe} 2), 11.3\left(\mathrm{CH}_{2} \mathrm{CH}_{2} \mathrm{CH}_{2} \mathrm{~N}\right), 17.1$ $\left(\mathrm{Si}^{0} \mathrm{CH}_{2}\right), 18.0\left(\mathrm{Si}^{1} \mathrm{CH}_{2} \mathrm{CH}_{2} \mathrm{CH}_{2} \mathrm{Si}^{2}\right), 18.1\left(\mathrm{Si}^{0} \mathrm{CH}_{2} \mathrm{CH}_{2}\right), 18.2\left(\mathrm{Si}^{1} \mathrm{CH}_{2} \mathrm{CH}_{2} \mathrm{CH}_{2} \mathrm{Si}^{2}\right), 18.5$ $\left(\mathrm{Si}^{0} \mathrm{CH}_{2} \mathrm{CH}_{2} \mathrm{CH}_{2}\right), 19.3\left(\mathrm{Si}^{1} \mathrm{CH}_{2} \mathrm{CH}_{2} \mathrm{CH}_{2} \mathrm{Si}^{2}\right), 22.4\left(\mathrm{CHMe}_{2}\right), 24.3\left(\mathrm{CH}_{2} \mathrm{CH}_{2} \mathrm{~N}\right), 51.7\left(\mathrm{CH}_{2} \mathrm{~N}\right)$, $52.2\left(\mathrm{CHMe}_{2}\right), 120.6,122.5,134.7(3 \times \mathrm{CH}) .{ }^{29} \mathrm{Si}\left\{{ }^{1} \mathrm{H}\right\}$ NMR (DMSO- $\left.d_{6}, 80 \mathrm{MHz}\right): \delta 0.79$ $\left(\mathrm{Si}^{0}\right), 1.04\left(\mathrm{Si}^{1}\right), 2.22\left(\mathrm{Si}^{2}\right)$. HRMS (ESI+) $\left[\mathrm{C}_{128} \mathrm{H}_{260} \mathrm{~N}_{16} \mathrm{Si}_{13} \mathrm{I}_{7}\right]^{+}$calc. $3276.1174[\mathrm{M}-\mathrm{I}]^{+}$, out of range; $\left[\mathrm{C}_{128} \mathrm{H}_{260} \mathrm{~N}_{16} \mathrm{Si}_{13} \mathrm{I}_{6}\right]^{2+}$ calc. $1574.6062[\mathrm{M}-2 \mathrm{I}]^{2+}$, found $1574.6064(100 \%)$; $\left[\mathrm{C}_{128} \mathrm{H}_{260} \mathrm{~N}_{16} \mathrm{Si}_{13} \mathrm{I}_{5}\right]^{3+}$ calc. 1007.4358 [M-3I $]^{3+}$, found $1007.4360(100 \%) ;\left[\mathrm{C}_{128} \mathrm{H}_{260} \mathrm{~N}_{16} \mathrm{Si}_{13} \mathrm{I}_{4}\right]^{4+}$ calc. $723.8506[\mathrm{M}-4 \mathrm{I}]^{4+}$, found $723.8510(100 \%) ;\left[\mathrm{C}_{128} \mathrm{H}_{260} \mathrm{~N}_{16} \mathrm{Si}_{13} \mathrm{I}_{3}\right]^{5+}$ calc. 553.6995 [M-5I $]^{5+}$, found $553.6983(100 \%) ;\left[\mathrm{C}_{128} \mathrm{H}_{260} \mathrm{~N}_{16} \mathrm{Si}_{13} \mathrm{I}_{2}\right]^{6+}$ calc. $440.2654[\mathrm{M}-6 \mathrm{I}]^{6+}$, found $440.2642(100 \%)$.

Dendrimer $\mathrm{G}_{1}(\mathrm{DippImI})_{4}$. The compound was prepared from dendrimer $\mathrm{G}_{\mathbf{1}}(\mathrm{PrI})_{4}$ $(0.25 \mathrm{~g}, 0.22 \mathrm{mmol})$ and 1-(2,6-diisopropylphenyl)imidazole $(0.27 \mathrm{~g}, 1.18 \mathrm{mmol})$. Yield: $0.26 \mathrm{~g}$ $(0.13 \mathrm{mmol}, 59 \%)$ of a yellow solid. ${ }^{1} \mathrm{H}$ NMR (DMSO- $d_{6}, 400 \mathrm{MHz}, \mathrm{H}-\mathrm{H}$ COSY): $\delta-0.05$ (s, $24 \mathrm{H}, \mathrm{SiMe} 2), 0.29-0.34\left(\mathrm{~m}, 8 \mathrm{H}, \mathrm{CH}_{2} \mathrm{CH}_{2} \mathrm{CH}_{2} \mathrm{~N}\right), 0.51-0.56\left(\mathrm{~m}, 16 \mathrm{H}, \mathrm{Si}^{0} \mathrm{CH}_{2} \mathrm{CH}_{2} \mathrm{CH}_{2}\right), 1.14(\mathrm{~d}$, $\left.J=6.8 \mathrm{~Hz}, 48 \mathrm{H}, \mathrm{Me}_{2} \mathrm{CH}\right), 1.28-1.33\left(\mathrm{~m}, 8 \mathrm{H}, \mathrm{Si}^{0} \mathrm{CH}_{2} \mathrm{CH}_{2}\right), 1.82-1.89\left(\mathrm{~m}, 8 \mathrm{H}, \mathrm{CH}_{2} \mathrm{CH}_{2} \mathrm{~N}\right), 2.25$ (hept, $\left.J=6.8 \mathrm{~Hz}, 8 \mathrm{H}, \mathrm{Me}_{2} \mathrm{CH}\right), 4.29\left(\mathrm{t}, J=6.3 \mathrm{~Hz}, 8 \mathrm{H}, \mathrm{CH}_{2} \mathrm{~N}\right), 7.47\left(\mathrm{~d}, J=7.8 \mathrm{~Hz}, 8 \mathrm{H}, \mathrm{CH}_{P h}\right)$, $7.64\left(\mathrm{t}, J=7.8 \mathrm{~Hz}, 4 \mathrm{H}, \mathrm{CH}_{P h}\right), 8.13,8.16,9.64\left(3 \times \mathrm{t}, J=1.7 \mathrm{~Hz}, 3 \times 4 \mathrm{H}, \mathrm{CH}_{I m}\right) .{ }^{13} \mathrm{C}\left\{{ }^{1} \mathrm{H}\right\}$ NMR (DMSO-d $\left.d_{6}, 101 \mathrm{MHz}, \mathrm{HSQC}, \mathrm{HMBC}\right): \delta-3.6\left(\mathrm{SiMe}_{2}\right), 11.0\left(\mathrm{CH}_{2} \mathrm{CH}_{2} \mathrm{CH}_{2} \mathrm{~N}\right), 16.9$ $\left(\mathrm{Si}^{0} \mathrm{CH}_{2}\right), 18.1\left(\mathrm{Si}^{0} \mathrm{CH}_{2} \mathrm{CH}_{2}\right), 19.3\left(\mathrm{Si}^{0} \mathrm{CH}_{2} \mathrm{CHCH}_{2}\right), 23.7,23.8\left(\mathrm{CHMe}_{2}\right), 23.9\left(\mathrm{CH}_{2} \mathrm{CH}_{2} \mathrm{~N}\right)$, $28.1\left(\mathrm{CHMe}_{2}\right), 52.1\left(\mathrm{CH}_{2} \mathrm{~N}\right), 123.4\left(\mathrm{CH}_{I m}\right), 124.4\left(2 \mathrm{CH}_{P h}\right), 125.2\left(\mathrm{CH}_{I m}\right), 130.5\left(\mathrm{~N}-\mathrm{C}_{\mathrm{q}}\right), 131.5$ $\left(\mathrm{CH}_{P h}\right), 137.6\left(\mathrm{CH}_{I m}\right), 145.0\left(2 \mathrm{iPr}-\mathrm{C}_{\mathrm{q}}\right) .{ }^{29} \mathrm{Si}\left\{{ }^{1} \mathrm{H}\right\} \mathrm{NMR}$ (DMSO-d $\left.6,80 \mathrm{MHz}\right): \delta 0.77\left(\mathrm{Si}^{0}\right)$, $2.23\left(\mathrm{Si}^{1}\right)$. HRMS (ESI+) $\left[\mathrm{C}_{92} \mathrm{H}_{152} \mathrm{~N}_{8} \mathrm{Si}_{5} \mathrm{I}_{3}\right]^{+}$calc. $1890.8410[\mathrm{M}-\mathrm{I}]^{+}$, found $1890.8392(100 \%)$; $\left[\mathrm{C}_{92} \mathrm{H}_{152} \mathrm{~N}_{8} \mathrm{Si}_{5} \mathrm{I}_{2}\right]^{2+}$ calc. $881.9545[\mathrm{M}-2 \mathrm{I}]^{2+}$, found $881.9556(100 \%) ;\left[\mathrm{C}_{92} \mathrm{H}_{152} \mathrm{~N}_{8} \mathrm{Si}_{5} \mathrm{I}\right]^{3+}$ calc. $545.6680[\mathrm{M}-3 \mathrm{II}]^{3+}$, found $545.6674(100 \%) ;\left[\mathrm{C}_{92} \mathrm{H}_{152} \mathrm{~N}_{8} \mathrm{Si}_{5}\right]^{4+}$ calc. $377.5247[\mathrm{M}-4 \mathrm{II}]^{4+}$, found $377.5241(100 \%)$.

Dendrimer $\mathbf{G}_{\mathbf{2}}(\operatorname{DippImI})_{\mathbf{8}}$. The compound was prepared from dendrimer $\mathbf{G}_{\mathbf{2}}(\operatorname{PrI})_{\mathbf{8}}$ $(0.26 \mathrm{~g}, 0.10 \mathrm{mmol})$ and 1-(2,6-diisopropylphenyl)imidazole $(0.25 \mathrm{~g}, 1.10 \mathrm{mmol})$. Yield: $0.24 \mathrm{~g}(55 \mu \mathrm{mol}, 53 \%)$ of a yellow solid. ${ }^{1} \mathrm{H}$ NMR (DMSO- $d_{6}, 400 \mathrm{MHz}, \mathrm{H}-\mathrm{H}$ COSY): $\delta$ $-0.11(\mathrm{~s}, 12 \mathrm{H}, \mathrm{SiMe}),-0.05$ (s, 48H, SiMe $), 0.29-0.33\left(\mathrm{~m}, 16 \mathrm{H}, \mathrm{CH}_{2} \mathrm{CH}_{2} \mathrm{CH}_{2} \mathrm{~N}\right), 0.51-0.58(\mathrm{~m}$, 
$\left.48 \mathrm{H}, \mathrm{Si}^{1} \mathrm{CH}_{2} \mathrm{CH}_{2} \mathrm{CH}_{2}\right), 1.14\left(\mathrm{~d}, J=6.9 \mathrm{~Hz}, 96 \mathrm{H}, \mathrm{Me}_{2} \mathrm{CH}\right), 1.29-1.33\left(\mathrm{~m}, 24 \mathrm{H}, \mathrm{Si}^{1} \mathrm{CH}_{2} \mathrm{CH}_{2}\right)$, 1.81-1.88 (m, 16H, $\mathrm{CH}_{2} \mathrm{CH}_{2} \mathrm{~N}$ ), 2.24 (hept, $\left.J=6.9 \mathrm{~Hz}, 16 \mathrm{H}, \mathrm{Me}_{2} \mathrm{CH}\right), 4.28$ (brs, $16 \mathrm{H}, \mathrm{CH}_{2} \mathrm{~N}$ ), $7.46\left(\mathrm{~d}, J=7.8 \mathrm{~Hz}, 16 \mathrm{H}, \mathrm{CH}_{P h}\right), 7.64\left(\mathrm{t}, J=7.8 \mathrm{~Hz}, 8 \mathrm{H}, \mathrm{CH}_{P h}\right), 8.13$ (brs, $\left.16 \mathrm{H}, \mathrm{CH}_{I m}\right), 9.62$ (brs, $\left.8 \mathrm{H}, \mathrm{CH}_{I m}\right) .{ }^{13} \mathrm{C}\left\{{ }^{1} \mathrm{H}\right\}$ NMR (DMSO- $\left.d_{6}, 101 \mathrm{MHz}, \mathrm{HSQC}, \mathrm{HMBC}\right): \delta-4.9(\mathrm{SiMe}),-3.6$ (SiMe $)$, $10.9\left(\mathrm{CH}_{2} \mathrm{CH}_{2} \mathrm{CH}_{2} \mathrm{~N}\right), 17.1\left(\mathrm{Si}^{0} \mathrm{CH}_{2}\right), 18.0\left(\mathrm{Si}^{1} \mathrm{CH}_{2} \mathrm{CH}_{2} \mathrm{CH}_{2} \mathrm{Si}^{2}\right), 18.1\left(\mathrm{Si}^{0} \mathrm{CH}_{2} \mathrm{CH}_{2}\right)$, $18.3\left(\mathrm{Si}^{1} \mathrm{CH}_{2} \mathrm{CH}_{2} \mathrm{CH}_{2} \mathrm{Si}^{2}\right), 18.5\left(\mathrm{Si}^{0} \mathrm{CH}_{2} \mathrm{CH}_{2} \mathrm{CH}_{2}\right), 19.3\left(\mathrm{Si}^{1} \mathrm{CH}_{2} \mathrm{CH}_{2} \mathrm{CH}_{2} \mathrm{Si}^{2}\right), 23.7,23.8$ $\left(\mathrm{Me}{ }_{2} \mathrm{CH}\right), 23.9\left(\mathrm{CH}_{2} \mathrm{CH}_{2} \mathrm{~N}\right), 28.1(\mathrm{CHMe}), 52.1\left(\mathrm{CH}_{2} \mathrm{~N}\right), 123.4\left(\mathrm{CH}_{I m}\right), 124.4\left(2 \mathrm{CH}_{P h}\right)$, 125.2 $\left(\mathrm{CH}_{I m}\right), 130.5\left(\mathrm{~N}-\mathrm{C}_{\mathrm{q}}\right), 131.5\left(\mathrm{CH}_{P h}\right), 137.6\left(\mathrm{CH}_{I m}\right), 145.0\left(2 i \operatorname{Pr}-\mathrm{C}_{\mathrm{q}}\right) .{ }^{29} \mathrm{Si}\left\{{ }^{1} \mathrm{H}\right\} \mathrm{NMR}$ (DMSO- $\left.d_{6}, 80 \mathrm{MHz}\right): \delta 0.81\left(\mathrm{Si}^{0}\right), 1.06\left(\mathrm{Si}^{1}\right), 2.21\left(\mathrm{Si}^{2}\right)$. HRMS (ESI+) $\left[\mathrm{C}_{200} \mathrm{H}_{340} \mathrm{~N}_{16} \mathrm{Si}_{13} \mathrm{I}_{7}\right]^{+}$ calc. $4221.7459[\mathrm{M}-\mathrm{I}]^{+}$, out of range; $\left[\mathrm{C}_{200} \mathrm{H}_{340} \mathrm{~N}_{16} \mathrm{Si}_{13} \mathrm{I}_{6}\right]^{2+}$ calc. $2047.4204[\mathrm{M}-2 \mathrm{I}]^{2+}$, found $2047.4186(100 \%) ;\left[\mathrm{C}_{200} \mathrm{H}_{340} \mathrm{~N}_{16} \mathrm{Si}_{13} \mathrm{I}_{5}\right]^{3+}$ calc. $1322.6453[\mathrm{M}-3 \mathrm{II}]^{3+}$, found $1322.6446(100 \%)$; $\left[\mathrm{C}_{200} \mathrm{H}_{340} \mathrm{~N}_{16} \mathrm{Si}_{13} \mathrm{I}_{4}\right]^{4+}$ calc. $960.2577[\mathrm{M}-4 \mathrm{I}]^{4+}$, found $960.2585(100 \%) ;\left[\mathrm{C}_{200} \mathrm{H}_{340} \mathrm{~N}_{16} \mathrm{Si}_{13} \mathrm{I}_{3}\right]^{5+}$ calc. $742.8252[\mathrm{M}-5 \mathrm{I}]^{5+}$, found $742.8249(100 \%) ;\left[\mathrm{C}_{200} \mathrm{H}_{340} \mathrm{~N}_{16} \mathrm{Si}_{13} \mathrm{I}_{2}\right]^{6+}$ calc. 597.8701 $[\mathrm{M}-6 \mathrm{I}]^{6+}$, found $597.8712(100 \%) ;\left[\mathrm{C}_{200} \mathrm{H}_{340} \mathrm{~N}_{16} \mathrm{Si}_{13} \mathrm{I}\right]^{7+}$ calc. $494.3308[\mathrm{M}-7 \mathrm{II}]^{7+}$, found $494.3315(100 \%)$.

Dendrimer $\mathrm{G}_{3}(\mathrm{DippImI})_{16}$. The compound was prepared from dendrimer $\mathrm{G}_{\mathbf{3}}(\operatorname{PrI})_{\mathbf{1 6}}$ $(0.27 \mathrm{~g}, 51 \mu \mathrm{mol})$ and 1-(2,6-diisopropylphenyl)imidazole (0.24 g, $1.06 \mathrm{mmol})$. Yield: $0.26 \mathrm{~g}$ $(29 \mu \mathrm{mol}, 58 \%)$ of a brownish yellow viscous liquid. ${ }^{1} \mathrm{H}$ NMR (DMSO- $d_{6}, 400 \mathrm{MHz}$, $\mathrm{H}-\mathrm{H}$ COSY): $\delta-0.11$ (brs, $\left.36 \mathrm{H}, \mathrm{SiMe}, \mathrm{Si}^{2} M e_{2}\right),-0.06\left(\mathrm{~s}, 96 \mathrm{H}, \mathrm{Si}^{3} M e_{2}\right), 0.32(\mathrm{~m}, 32 \mathrm{H}$, $\left.\mathrm{CH}_{2} \mathrm{CH}_{2} \mathrm{CH}_{2} \mathrm{~N}\right), 0.54\left(\mathrm{~m}, 112 \mathrm{H}, \mathrm{SiCH}_{2} \mathrm{CH}_{2} \mathrm{CH}_{2} \mathrm{Si}\right), 1.13\left(\mathrm{~d}, \mathrm{~J}=6.8 \mathrm{~Hz}, 192 \mathrm{H}, \mathrm{Me}_{2} \mathrm{CH}\right)$, $1.29\left(\mathrm{~m}, 56 \mathrm{H}, \mathrm{SiCH}_{2} \mathrm{CH}_{2} \mathrm{CH}_{2} \mathrm{Si}\right), 1.87\left(\mathrm{~m}, 32 \mathrm{H}, \mathrm{CH}_{2} \mathrm{CH}_{2} \mathrm{~N}\right), 2.26$ (hept, $J=6.9 \mathrm{~Hz}, 32 \mathrm{H}$, $\left.\mathrm{Me}_{2} \mathrm{CH}\right), 4.33\left(\mathrm{brs}, 32 \mathrm{H}, \mathrm{CH}_{2} \mathrm{~N}\right), 7.46\left(\mathrm{~d}, J=7.8 \mathrm{~Hz}, 32 \mathrm{H}, \mathrm{CH}_{P h}\right), 7.64(\mathrm{t}, J=7.8 \mathrm{~Hz}, 16 \mathrm{H}$, $\left.\mathrm{CH}_{P h}\right), 8.14,8.22,9.71\left(3 \times\right.$ brs, $\left.\left.3 \times 16 \mathrm{H}, \mathrm{CH}_{I m}\right) .{ }^{13} \mathrm{C}_{\{}{ }^{1} \mathrm{H}\right\}$ NMR (DMSO- $d_{6}, 101 \mathrm{MHz}, \mathrm{HSQC}$, HMBC): $\delta-4.9\left(\mathrm{Si}^{1,2} \mathrm{Me}\right),-3.6\left(\mathrm{Si}^{3} \mathrm{Me} e_{2}\right), 10.9\left(\mathrm{CH}_{2} \mathrm{CH}_{2} \mathrm{CH}_{2} \mathrm{~N}\right)$, not detected $\left(\mathrm{Si}^{0} \mathrm{CH}_{2} \mathrm{CH}_{2} \mathrm{CH}_{2}\right)$, $18.0\left(\mathrm{Si}^{2} \mathrm{CH}_{2} \mathrm{CH}_{2} \mathrm{CH}_{2} \mathrm{Si}^{3}\right), 18.1,18.4\left(\mathrm{Si}^{1} \mathrm{CH}_{2} \mathrm{CH}_{2} \mathrm{CH}_{2} \mathrm{Si}^{2}\right), 18.2\left(\mathrm{Si}^{2} \mathrm{CH}_{2} \mathrm{CH}_{2} \mathrm{CH}_{2} \mathrm{Si}^{3}\right), 19.3$ $\left(\mathrm{Si}^{2} \mathrm{CH}_{2} \mathrm{CH}_{2} \mathrm{CH}_{2} \mathrm{Si}^{3}\right)$, 23.7, $23.8\left(\mathrm{Me}_{2} \mathrm{CH}\right), 24.0\left(\mathrm{CH}_{2} \mathrm{CH}_{2} \mathrm{~N}\right), 28.1(\mathrm{CHMe}), 52.1\left(\mathrm{CH}_{2} \mathrm{~N}\right)$, $123.4\left(\mathrm{CH}_{I m}\right), 124.4\left(2 \mathrm{CH}_{P h}\right), 125.2\left(\mathrm{CH}_{I m}\right), 130.4\left(\mathrm{~N}-\mathrm{C}_{\mathrm{q}}\right), 131.5\left(\mathrm{CH}_{P h}\right), 137.6\left(\mathrm{CH}_{I m}\right), 145.0$ $\left(2 i \operatorname{Pr}-C_{\mathrm{q}}\right) .{ }^{29} \mathrm{Si}\left\{{ }^{1} \mathrm{H}\right\}$ NMR (DMSO- $\left.d_{6}, 80 \mathrm{MHz}\right): \delta$ not detected $\left(\mathrm{Si}^{0}\right), 1.04\left(\mathrm{Si}^{1,2}\right), 2.18$ $\left(\mathrm{Si}^{3}\right)$. HRMS (ESI+) $\left[\mathrm{C}_{416} \mathrm{H}_{716} \mathrm{~N}_{32} \mathrm{Si}_{29} \mathrm{I}_{15}\right]^{+}$calc. $8883.6098[\mathrm{M}-\mathrm{I}]^{+},\left[\mathrm{C}_{416} \mathrm{H}_{716} \mathrm{~N}_{32} \mathrm{Si}_{29} \mathrm{I}_{14}\right]^{2+}$ calc. $4378.3524[\mathrm{M}-2 \mathrm{I}]^{2+}$, both out of range; $\left[\mathrm{C}_{416} \mathrm{H}_{716} \mathrm{~N}_{32} \mathrm{Si}_{29} \mathrm{I}_{13}\right]^{3+}$ calc. 2836.5999 [M$3 \mathrm{I}]^{3+}$, found $2836.6001(100 \%) ;\left[\mathrm{C}_{416} \mathrm{H}_{716} \mathrm{~N}_{32} \mathrm{Si}_{29} \mathrm{I}_{12}\right]^{4+}$ calc. $2125.7237[\mathrm{M}-4 \mathrm{II}]^{4+}$, found $2125.7254(100 \%) ;\left[\mathrm{C}_{416} \mathrm{H}_{716} \mathrm{~N}_{32} \mathrm{Si}_{29} \mathrm{I}_{11}\right]^{5+}$ calc. $1675.1979[\mathrm{M}-5 \mathrm{I}]^{5+}$, found $1675.2001(100 \%)$; $\left[\mathrm{C}_{416} \mathrm{H}_{716} \mathrm{~N}_{32} \mathrm{Si}_{29} \mathrm{I}_{10}\right]^{6+}$ calc. 1374.8474 [M-6I] ${ }^{6+}$, found $1374.8471(100 \%) ;\left[\mathrm{C}_{416} \mathrm{H}_{716} \mathrm{~N}_{32} \mathrm{Si}_{29} \mathrm{I}_{9}\right]^{7+}$ calc. $1160.3113[\mathrm{M}-7 \mathrm{I}]^{7+}$, found $1160.3122(100 \%) ;\left[\mathrm{C}_{416} \mathrm{H}_{716} \mathrm{~N}_{32} \mathrm{Si}_{29} \mathrm{I}_{8}\right]^{8+}$ calc. $999.4093[\mathrm{M}-$ $8 \mathrm{I}]^{8+}$, found $999.4080(100 \%)$.

\subsection{Redox Esterification of Cinnamaldehyde}

In a typical experiment, $2.8 \mathrm{mg}(5.0 \mu \mathrm{mol})$ of $\mathbf{G}_{0}$ DippImI was placed in a Schlenk flask which was then three times evacuated and refilled with argon. Cinnamaldehyde (66 mg, $0.50 \mathrm{mmol})$, alcohol $(2.00 \mathrm{mmol}), \mathrm{DBU}(1.5 \mathrm{mg}, 0.01 \mathrm{mmol})$ and internal standard for GC dioctyl phthalate $(59 \mathrm{mg}, 0.15 \mathrm{mmol}$ ) followed by $5 \mathrm{~mL}$ of toluene were added under the flow of argon. All components were thoroughly mixed, $30 \mu \mathrm{L}$ sample was withdrawn for GC analysis and the reaction mixture was heated for a specified time in the oil bath of constant temperature $\left(100{ }^{\circ} \mathrm{C}\right.$ unless otherwise noted). Then the mixture was let to cool down and analyzed by GC. In case that samples were taken in the course of experiment for kinetic studies, for each point $30 \mu \mathrm{L}$ of the reaction mixture was withdrawn via syringe under the flow of argon, dissolved in cold DCM and stored in refrigerator till analysis.

For the purpose of substrate screening of alcohols, a stock solution of cinnamaldehyde $\left(0.1 \mathrm{~mol} . \mathrm{L}^{-1}\right)$, DBU $\left(4.0 \mathrm{mmol} . \mathrm{L}^{-1}\right)$ and dioctyl phthalate $\left(0.03 \mathrm{~mol} . \mathrm{L}^{-1}\right)$ in toluene and stock solutions of precatalysts in $\mathrm{MeOH}\left(20 \mathrm{mmol} . \mathrm{L}^{-1}\right.$ with respect to active centers) were prepared and stored under argon at $4{ }^{\circ} \mathrm{C}$. The composition of aldehyde stock solution was confirmed by GC-FID. In a typical experiment, $100 \mu \mathrm{L}$ of a stock solution of a given precatalyst was placed in a Schlenk flask and the solvent was evaporated in vacuum. The flask was then three times evacuated and refilled with argon and $1.0 \mathrm{~mL}$ of substrate stock 
solution was added under the flow of argon followed by $0.4 \mathrm{mmol}$ of the corresponding alcohol. The reaction mixture was heated for a specified time to $100{ }^{\circ} \mathrm{C}$ in the oil bath and samples for GC were taken to follow the reaction progress. For the reactions with higher catalyst loading the amount of precatalyst stock solutions and the concentration of DBU in the stock solution were correspondingly increased.

The procedure for substrate screening of aldehydes was analogous, using stock solution of benzyl alcohol $\left(0.4 \mathrm{~mol} . \mathrm{L}^{-1}\right), \mathrm{DBU}\left(0.01 \mathrm{~mol} . \mathrm{L}^{-1}\right)$ and dioctyl phthalate $\left(0.03 \mathrm{~mol} . \mathrm{L}^{-1}\right)$ in toluene to which the particular aldehyde $(0.1 \mathrm{mmol})$ was added. Before the heating of the reaction mixture, a sample for GC was taken to confirm the ratio of the aldehyde to the internal standard.

Recycling experiments were performed on a larger scale without internal standard. The first cycle was set up with $1.00 \mathrm{mmol}$ of cinnamaldehyde $(132 \mathrm{mg}), 4.00 \mathrm{mmol}$ of benzyl alcohol (433 mg), $25.0 \mu \mathrm{mol}$ of $\mathbf{G}_{1}(\text { DippImI })_{4}(50.0 \mathrm{mg})$ and $0.15 \mathrm{mmol}$ of DBU $(23 \mathrm{mg})$ in $5 \mathrm{~mL}$ of toluene; the batch size in the following cycles was adapted to correspond with the amount of recycled precatalyst. The same concentration of all components at the start of all reaction runs was maintained, except benzyl alcohol, 50\% of which was replaced by tert-butyl alcohol. After each cycle, $\mathrm{G}_{\mathbf{1}}(\mathrm{DippImI})_{4}$ was separated from the reaction mixture by nanofiltration (vide supra), dried, weighted and checked by ESI MS. The product containing permeate was evaporated in vacuum, dissolved in dichloromethane, filtered through a short pad of silica gel and evaporated to dryness to afford the target ester.

\subsection{Organic Solvent Nanofiltration}

Nanofiltration was carried out using solvent resistant stirred cell (Millipore) equipped with $1 \mathrm{kDa}$ MWCO regenerated cellulose ultrafiltration discs Ultracel ${ }^{\circledR}$ (Millipore) and PTFE encapsulated O-rings (ERIKS), with nitrogen as a driving gas. Reaction mixture was quantitatively transferred into the cell, diluted with methanol to a total volume of $25 \mathrm{~mL}$ and passed through the membrane until the residual volume $1 \mathrm{~mL}$ of retentate was reached. The retentate was diluted with $20 \mathrm{~mL}$ of methanol and filtered; this procedure was repeated 3 times and subsequently the retentate was withdrawn via cannula. The inner space of the cell was washed with $3 \times 2 \mathrm{~mL}$ of methanol and the retentate and washings were combined and evaporated under vacuum to recover the dendritic catalyst. The cell was not disassembled and it was used directly for the next separation cycle. The product was obtained after the permeate workup.

\section{Conclusions}

We have demonstrated the feasibility of immobilization of imidazolium salts on the dendrimer periphery and their use as multivalent carbene precursors in NHC catalysed redox esterification of $\alpha, \beta$-enals. Although the immobilization led to expected decrease of catalytic activity, the deactivation can be limited by appropriate substitution on imidazolium. From the studied types, Dipp substituted catalysts were least influenced and exhibited high activity and selectivity in the reactions with primary alcohols. On the other hand, the bulky Dipp substituent hinders the reaction with secondary alcohols, for which a clear relationship between the steric hindrance of the alcohol nucleophile and the yield and purity of the product was observed. This drop in both activity and selectivity is much less pronounced for methyl substituted dendritic NHCs, which makes them more competent catalysts in the case of alicyclic alcohols. The concept of dendritic catalyst recycling by nanofiltration, although not new, has been shown as especially suited for this class of active species. The separation from the reaction mixture was effective and the catalyst recovery was high even for the first generation Dipp imidazolium dendrimer. Moreover, OSN induced an increase of catalytic activity, partially compensating for the negative effect of immobilization. Such "activation" can be ascribed to a shift in the equilibrium between imidazolium iodide and the corresponding carbene induced by separation of DBU salt during nanofiltration. Dipp substituted NHCs proved to be particularly stable. At least a part of these carbene moieties was present in the recycled material even after several 
weeks and it was capable to induce the redox esterification without added base which can, together with catalyst recycling, contribute to higher atom economy of the process.

Supplementary Materials: The following are available online at https:/ /www.mdpi.com/article/ 10.3390 /catal11111317/s1, NMR spectra of all prepared precatalysts; synthesis and characterization of previously unpublished esters, EI-MS spectra of all identified products from redox esterification experiments; extended results of substrate screening of aldehydes; selected HRMS spectra of recycled $\mathrm{G}_{\mathbf{1}}(\text { DippImI })_{4}$.

Author Contributions: Conceptualization, A.K., J.Č. and T.S.; data curation, A.K.; funding acquisition, J.Č.; investigation, A.K., K.K., L.Č.Š., P.C., M.M. and J.K.; project administration, J.Č. and T.S.; supervision, A.K. and M.M.; visualization, A.K.; writing-original draft, A.K. and T.S.; writingreview \& editing, A.K., L.Č.S., P.C. and T.S. All authors have read and agreed to the published version of the manuscript.

Funding: This research and the APC were funded by ERDF/ESF (project "UniQSurf-Centre of Biointerfaces and Hybrid Functional Materials" No. CZ.02.1.01/0.0/0.0/17_048/0007411).

Conflicts of Interest: The authors declare no conflict of interest.

\section{References}

1. Xin, B.; Hao, J. Imidazolium-Based Ionic Liquids Grafted on Solid Surfaces. Chem. Soc. Rev. 2014, 43, 7171-7187. [CrossRef] [PubMed]

2. Zhang, S.; Zhang, J.; Zhang, Y.; Deng, Y. Nanoconfined Ionic Liquids. Chem. Rev. 2017, 117, 6755-6833. [CrossRef] [PubMed]

3. Fournier, A.H.; de Robillard, G.; Devillers, C.H.; Plasseraud, L.; Andrieu, J. Imidazolium and Potassium Hydrogen Carbonate Salts as Ecofriendly Organocatalysts for Oxazolidinone Synthesis. Eur. J. Org. Chem. 2016, 2016, 3514-3518. [CrossRef]

4. Chakraborty Ghosal, N.; Santra, S.; Das, S.; Hajra, A.; Zyryanov, G.V.; Majee, A. Organocatalysis by an Aprotic Imidazolium Zwitterion: Regioselective Ring-Opening of Aziridines and Applicable to Gram Scale Synthesis. Green Chem. 2016, 18, 565-574. [CrossRef]

5. Ghosh, D.; Lee, J.-Y.; Liu, C.-Y.; Chiang, Y.-H.; Lee, H.M. Direct C-H Arylations of Unactivated Arenes Catalyzed by AmidoFunctionalized Imidazolium Salts. Adv. Synth. Catal. 2014, 356, 406-410. [CrossRef]

6. Bobbink, F.D.; Dyson, P.J. Synthesis of Carbonates and Related Compounds Incorporating $\mathrm{CO}_{2}$ using Ionic Liquid-Type Catalysts: State-of-the-Art and Beyond. J. Catal. 2016, 343, 52-61. [CrossRef]

7. Büttner, H.; Longwitz, L.; Steinbauer, J.; Wulf, C.; Werner, T. Recent Developments in the Synthesis of Cyclic Carbonates from Epoxides and $\mathrm{CO}_{2}$. Top. Curr. Chem. 2017, 375, 1-56. [CrossRef]

8. Marion, N.; Díez-González, S.; Nolan, S.P. N-Heterocyclic Carbenes as Organocatalysts. Angew. Chem. Int. Ed. 2007, 46, 2988-3000. [CrossRef]

9. Ryan, S.J.; Candish, L.; Lupton, D.W. Acyl Anion Free N-Heterocyclic Carbene Organocatalysis. Chem. Soc. Rev. 2013, 42, 4906-4917. [CrossRef]

10. Grossmann, A.; Enders, D. N-Heterocyclic Carbene Catalyzed Domino Reactions. Angew. Chem. Int. Ed. 2012, 51, 314-325. [CrossRef]

11. Feroci, M.; Chiarotto, I.; Inesi, A. Advances in the Knowledge of N-Heterocyclic Carbenes Properties. The Backing of the Electrochemical Investigation. Catalysts 2016, 6, 178. [CrossRef]

12. Menon, R.S.; Biju, A.T.; Nair, V. Recent Advances in Employing Homoenolates Generated by N-Heterocyclic Carbene (NHC) Catalysis in Carbon-Carbon Bond-Forming Reactions. Chem. Soc. Rev. 2015, 44, 5040-5052. [CrossRef]

13. De Sarkar, S.; Biswas, A.; Samanta, R.C.; Studer, A. Catalysis with N-Heterocyclic Carbenes under Oxidative Conditions. Chemistry 2013, 19, 4664-4678. [CrossRef] [PubMed]

14. Ma, S.; Toy, P. Self-Supported N-Heterocyclic Carbenes and Their Use as Organocatalysts. Molecules 2016, 21, 1100. [CrossRef] [PubMed]

15. Cywar, R.M.; Wang, L.; Chen, E.Y.-X. Thermally Regulated Recyclable Carbene Catalysts for Upgrading of Biomass Furaldehydes. ACS Sustain. Chem. Eng. 2019, 7, 1980-1988. [CrossRef]

16. Coupillaud, P.; Pinaud, J.; Guidolin, N.; Vignolle, J.; Fèvre, M.; Veaudecrenne, E.; Mecerreyes, D.; Taton, D. Poly(Ionic Liquid)s Based on Imidazolium Hydrogen Carbonate Monomer Units as Recyclable Polymer-Supported N-Heterocyclic Carbenes: Use in Organocatalysis. J. Polym. Sci. Part. A Polym. Chem. 2013, 51, 4530-4540. [CrossRef]

17. Barrett, A.G.M.; Love, A.C.; Tedeschi, L. ROMPgel-Supported Thiazolium Iodide: An Efficient Supported Organic Catalyst for Parallel Stetter Reactions. Org. Lett. 2004, 6, 3377-3380. [CrossRef]

18. Strašák, T.; Št'astná, L.Č.; Bílková, V.; Skoupá, V.; Karban, J.; Cuřínová, P.; Čermák, J. Synthesis and Fluorophilicity of Compounds with Tris(3,3,4,4,5,5,6,6,7,7,8,8,8-Tridecafluorooctyl)Silyl Substituent. J. Fluor. Chem. 2015, 178, 23-29. [CrossRef]

19. Strašák, T.; Čermák, J.; Červenková Št’astná, L.; Sýkora, J.; Fajgar, R. Cobalt(I) and Cobalt(III) Cyclopentadienyl Complexes with New Silicon-Branched Fluorous Tags. J. Fluor. Chem. 2014, 159, 15-20. [CrossRef] 
20. Červenková Št'astná, L.; Bílková, V.; Cézová, T.; Cuřínová, P.; Karban, J.; Čermák, J.; Krupková, A.; Strašák, T. Imidazolium Based Fluorous N-Heterocyclic Carbenes as Effective and Recyclable Organocatalysts for Redox Esterification. Eur. J. Org. Chem. 2020, 2020, 3591-3598. [CrossRef]

21. Liu, Y.; Cheng, W.; Zhang, Y.; Sun, J.; Zhang, S. Controllable Preparation of Phosphonium-Based Polymeric Ionic Liquids as Highly Selective Nanocatalysts for the Chemical Conversion of $\mathrm{CO}_{2}$ with Epoxides. Green Chem. 2017, 19, 2184-2193. [CrossRef]

22. Müllerová, M.; Šabata, S.; Matoušek, J.; Kormunda, M.; Holubová, J.; Bálková, R.; Petričkovič, R.; Koštejn, M.; Kupčík, J.; Fajgar, R.; et al. Organoclays with Carbosilane Dendrimers Containing Ammonium or Phosphonium Groups. New J. Chem. 2018, 42, 1187-1196. [CrossRef]

23. Ding, M.; Jiang, H.L. Incorporation of Imidazolium-Based Poly(Ionic Liquid)s into a Metal-Organic Framework for $\mathrm{CO}_{2}$ Capture and Conversion. ACS Catal. 2018, 8, 3194-3201. [CrossRef]

24. Poli, R. Effects of Nanoconfinement on Catalysis; Poli, R., Ed.; Springer International Publishing: Cham, The Netherlands, 2017. [CrossRef]

25. Tomalia, D.A. Dendrimers and Other Dendritic Polymers; Fréchet, J.M.J., Tomalia, D.A., Eds.; John Wiley \& Sons, Ltd.: Chichester, UK, 2001; Volume 1. [CrossRef]

26. Perrier, A.; Keller, M.; Caminade, A.M.; Majoral, J.P.; Ouali, A. Efficient and Recyclable Rare Earth-Based Catalysts for FriedelCrafts Acylations under Microwave Heating: Dendrimers Show the Way. Green Chem. 2013, 15, 2075-2080. [CrossRef]

27. Keller, M.; Perrier, A.; Linhardt, R.; Travers, L.; Wittmann, S.; Caminade, A.M.; Majoral, J.P.; Reiser, O.; Ouali, A. Dendrimers or Nanoparticles as Supports for the Design of Efficient and Recoverable Organocatalysts? Adv. Synth. Catal. 2013, 355, 1748-1754. [CrossRef]

28. Deng, G.-J.; Fan, Q.-H.; Chen, X.-M.; Liu, D.-S.; Chan, A.S.C. A Novel System Consisting of Easily Recyclable Dendritic Ru-BINAP Catalyst for Asymmetric Hydrogenation. Chem. Commun. 2002, 15, 1570-1571. [CrossRef]

29. Huang, Y.-Y.; He, Y.-M.; Zhou, H.-F.; Wu, L.; Li, B.-L.; Fan, Q.-H. Thermomorphic System with Non-Fluorous Phase-Tagged $\mathrm{Ru}$ (BINAP) Catalyst: Facile Liquid/Solid Catalyst Separation and Application in Asymmetric Hydrogenation. J. Org. Chem. 2006, 71, 2874-2877. [CrossRef]

30. Liu, J.; Ma, B.; Feng, Y.; He, Y.; Fan, Q.H. Dendritic $\left[\mathrm{RuCl}_{2}(\mathrm{BINAP})(\mathrm{DPEN})\right]$ Catalysts with “Sandwich" Multi-Layer Structure for Asymmetric Hydrogenation of Simple Aryl Ketones. Inorg. Chim. Acta 2014, 409, 106-111. [CrossRef]

31. Keller, M.; Collière, V.; Reiser, O.; Caminade, A.M.; Majoral, J.P.; Ouali, A. Pyrene-Tagged Dendritic Catalysts Noncovalently Grafted onto Magnetic Co/C Nanoparticles: An Efficient and Recyclable System for Drug Synthesis. Angew. Chem. Int. Ed. 2013, 52, 3626-3629. [CrossRef]

32. Bronstein, L.M. Magnetically Recoverable Catalysts with Dendritic Ligands for Enhanced Catalysis and Easy Separation. ChemCatChem 2015, 7, 1058-1060. [CrossRef]

33. Gaab, M.; Bellemin-Laponnaz, S.; Gade, L.H. "Catalysis in a Tea Bag": Synthesis, Catalytic Performance and Recycling of Dendrimer-Immobilised Bis- and Trisoxazoline Copper Catalysts. Chemistry 2009, 15, 5450-5462. [CrossRef] [PubMed]

34. Nemanashi, M.; Meijboom, R. "Cat in a Bag" Recycling of Dendrimer Encapsulated Au Nanoparticles by Use of Dialysis Membrane Bag in the Reduction of 4-Nitrophenol: Proof of Heterogeneous Catalysis. Catal. Commun. 2016, 83, 53-57. [CrossRef]

35. Hovestad, N.J.; Eggeling, E.B.; Heidbüchel, H.J.; Jastrzebski, J.T.B.H.; Kragl, U.; Keim, W.; Vogt, D.; Van Koten, G. Selective Hydrovinylation of Styrene in a Membrane Reactor: Use of Carbosilane Dendrimers with Hemilabile P,O Ligands. Angew. Chem. Int. Ed. 1999, 38, 1655-1658. [CrossRef]

36. Albrecht, M.; Hovestad, N.J.; Boersma, J.; Van Koten, G. Multiple Use of Soluble Metallodendritic Materials as Catalysts and Dyes. Chemistry 2001, 7, 1289-1294. [CrossRef]

37. Guerra, J.; Cantillo, D.; Kappe, C.O. Visible-Light Photoredox Catalysis Using a Macromolecular Ruthenium Complex: Reactivity and Recovery by Size-Exclusion Nanofiltration in Continuous Flow. Catal. Sci. Technol. 2016, 6, 4695-4699. [CrossRef]

38. Strašák, T.; Jaroschik, F.; Malý, M.; Čermák, J.; Sýkora, J.; Fajgar, R.; Karban, J.; Harakat, D. Titanocene Dichloride Complexes Bonded to Carbosilane Dendrimers via a Spacer of Variable Length-Molecular Dynamics Calculations and Catalysis of Allylic Coupling Reactions. Inorg. Chim. Acta 2014, 409, 137-146. [CrossRef]

39. Marchetti, P.; Jimenez Solomon, M.F.; Szekely, G.; Livingston, A.G. Molecular Separation with Organic Solvent Nanofiltration: A Critical Review. Chem. Rev. 2014, 114, 10735-10805. [CrossRef]

40. Červenková Št'astná, L.; Krupková, A.; Petrickovic, R.; Müllerová, M.; Matoušek, J.; Koštejn, M.; Cuřínová, P.; Jandová, V.; Šabata, S.; Strašák, T. Multivalent Bifunctional Carbosilane Dendrimer-Supported Ammonium and Phosphonium Organocatalysts for the Coupling of $\mathrm{CO}_{2}$ and Epoxides. ACS Sustain. Chem. Eng. 2020, 8, 11692-11703. [CrossRef]

41. Strašák, T.; Malý, J.; Wróbel, D.; Malý, M.; Herma, R.; Čermák, J.; Müllerová, M.; Št'astná, L.Č.; Cuřínová, P. Phosphonium Carbosilane Dendrimers for Biomedical Applications-Synthesis, Characterization and Cytotoxicity Evaluation. RSC Adv. 2017, 7, 18724-18744. [CrossRef]

42. Cuřínová, P.; Krupková, A.; Červenková Št'astná, L.; Müllerová, M.; Čermák, J.; Strašák, T. ESI-TOF Mass Spectrometry of Cationic Carbosilane Dendrimers: A Potent Tool for Characterization of Structural Defects. J. Mass Spectrom. 2018, 53, 986-996. [CrossRef]

43. Chan, A.; Scheidt, K.A. Conversion of $\alpha, \beta$-Unsaturated Aldehydes into Saturated Esters: An Umpolung Reaction Catalyzed by Nucleophilic Carbenes. Org. Lett. 2005, 7, 905-908. [CrossRef] [PubMed] 
44. Wang, M.H.; Barsoum, D.; Schwamb, C.B.; Cohen, D.T.; Goess, B.C.; Riedrich, M.; Chan, A.; Maki, B.E.; Mishra, R.K.; Scheidt, K.A. Catalytic, Enantioselective $\beta$-Protonation through a Cooperative Activation Strategy. J. Org. Chem. 2017, 82, 4689-4702. [CrossRef] [PubMed]

45. Mahatthananchai, J.; Bode, J.W. The Effect of the N-Mesityl Group in NHC-Catalyzed Reactions. Chem. Sci. 2012, 3, 192-197. [CrossRef] [PubMed]

46. Maki, B.E.; Patterson, E.V.; Cramer, C.J.; Scheidt, K.A. Impact of Solvent Polarity on N-Heterocyclic Carbene-Catalyzed $\beta$ Protonations of Homoenolate Equivalents. Org. Lett. 2009, 11, 3942-3945. [CrossRef]

47. Maki, B.E.; Chan, A.; Scheidt, K.A. Protonation of Homoenolate Equivalents Generated by N-Heterocyclic Carbenes. Synthesis 2008, 8, 1306-1315. [CrossRef]

48. Sohn, S.S.; Bode, J.W. Catalytic Generation of Activated Carboxylates from Enals: A Product-Determining Role for the Base. Org. Lett. 2005, 7, 3873-3876. [CrossRef]

49. Yatham, V.R.; Harnying, W.; Kootz, D.; Neudörfl, J.M.; Schlörer, N.E.; Berkessel, A. 1,4-Bis-Dipp/Mes-1,2,4-Triazolylidenes: Carbene Catalysts That Efficiently Overcome Steric Hindrance in the Redox Esterification of $\alpha$ - and $\beta$-Substituted $\alpha$, $\beta$-Enals. J. Am. Chem. Soc. 2016, 138, 2670-2677. [CrossRef]

50. de Saint Laumer, J.-Y.; Cicchetti, E.; Merle, P.; Egger, J.; Chaintreau, A. Quantification in Gas Chromatography: Prediction of Flame Ionization Detector Response Factors from Combustion Enthalpies and Molecular Structures. Anal. Chem. 2010, 82, 6457-6462. [CrossRef] 